\title{
VOTAR EN MADRID TRAS LA REVOLUCIÓN DE 1868. TÉCNICAS, PROCESOS Y PRÁCTICAS ELECTORALES
}

\section{VOTING IN MADRID AFTER THE SPANISH REVOLUTION OF 1868. TECHNIQUES, PROCESSES AND ELECTORAL PRACTICES}

\author{
Santiago de Miguel Salanova \\ Universidad Complutense de Madrid
}

\begin{abstract}
SUMARIO: I. LAS ELECCIONES DEL SEXENIO Y SUS NUEVAS POSIBILIDADES ANALÍTICAS A TRAVÉS DE UN CASO DE ESTUDIO: LOS COMICIOS GENERALES DE 1869 EN MADRID- II. LA COMPLEJA ARTICULACIÓN DE UNA PARTICIPACIÓN ELECTORAL SOCIALMENTE EXTENDIDA.- III. ARBITRAJE, MEDIACIÓN Y MOVILIZACIÓN DEL VOTO EN LOS PRIMEROS EJERCICIOS DEL SUFRAGIO UNIVERSAL.- IV. EL VOTO EN SU CONTEXTO.- V. CONCLUSIONES
\end{abstract}

Resumen: Este artículo analiza el escenario de iniciación politica abierto en Madrid tras la Revolución de 1868 y la aprobación del sufragio universal masculino. Desde la relectura de la documentación tramitada por el Ayuntamiento de Madrid en las elecciones generales de enero de 1869, se exploran tres cuestiones. Primero, el proceso de articulación de las culturas técnicas que guiaron la extensión social del voto. En segundo lugar, el papel de los actores políticos locales en el arbitraje y la mediación del sufragio desde las mesas electorales. Y finalmente, las particularidades que revistió la práctica del voto en el marco socio-comunitario de la ciudad, desde un enfoque microhistórico.

\begin{abstract}
This article analyses the framework of political initiation set up in Madrid after the Spanish Revolution of 1868 and the approval of the decree on the exercise of universal male suffrage. From a reinterpretation of the documentation processed by the City Council of Madrid for the general election of January 1869, three specific issues are discussed. Firstly, the articulation of the technical cultures that guided the social extension of the vote. Second, the role played by local political actors in arbitration and mediation of suffrage from the polling stations. And finally, the peculiarities of voting at social and community level, through a microhistorical approach.
\end{abstract}

\footnotetext{
Este artículo ha sido realizado en el marco de los siguientes proyectos de investigación: La sociedad urbana en España, 1860-1983. De los ensanches a las áreas metropolitanas, cambio social y modernización, PGC2018-096461-B-C41, Programa Estatal de Generación de Conocimiento y Fortalecimiento Científico y Tecnológico del Sistema de I+D+i financiado por Ministerio de Ciencia, Innovación y Universidades / Unión Europea. Fondo Europeo de Desarrollo Regional. MICINN/FEDER (Investigador principal: Luis Enrique Otero Carvajal) y "Gobernar la ciudad. La transición urbana como objeto político de los poderes locales en la España Contemporánea (19001936)", Ayudas para la realización de proyectos de I+D para Jóvenes Doctores. Ref: PR65/1922409. Convocatoria 2019. Entidades financiadoras: Comunidad de Madrid y Universidad Complutense de Madrid (Investigador principal: Santiago de Miguel Salanova). Asimismo, el autor ha contado con la financiación de la ayuda proporcionada por el Programa de Atracción de Talento de la Comunidad de Madrid, 2017, Modalidad 2 (Jóvenes doctores), Ficha: 2017T2/HUM-5216.
} 
Palabras clave: Madrid. Revolución de 1868. Sufragio universal masculino. Elecciones generales de 1869. Voto

Key Words: Madrid, 1868 Revolution, Universal male suffrage, General election of 1869 , Voting.

\section{LAS ELECCIONES DEL SEXENIO Y SUS NUEVAS POSIBILIDADES ANALÍTICAS A TRAVÉS DE UN CASO DE ESTUDIO: LOS COMICIOS GENERALES DE 1869 EN MADRID}

9 de noviembre de 1868. El Gobierno Provisional formado tras la Gloriosa publicaba en esa jornada el decreto sobre el sufragio universal masculino. Su puesta en marcha se justificó por la necesidad de armonizar la administración y la política del país con las aspiraciones del pueblo, expresadas en el movimiento revolucionario de septiembre. El decreto concentraba en un único corpus documental todas las disposiciones referidas a elecciones generales, provinciales y municipales, lo que respondía al deseo de fomentar entre la población comportamientos uniformes de cara a los comicios que se celebraran en lo sucesivo. En virtud de ello, todo elector debía adoptar la costumbre politica de "emitir su voto siempre en la misma forma, siempre en su propio domicilio y sin las dificultades y los compromisos locales que en el antiguo sistema cohibian su libre voluntad"1.

El ejercicio del sufragio universal masculino en los primeros compases del Sexenio Democrático ha sido una temática ampliamente abordada desde los estudios de Martínez Cuadrado². Por lo general, el análisis de la normativa electoral se ha aplicado para todo el período comprendido entre la Revolución de 1868 y la Primera República, en aras de seguir la evolución de la dinámica politica del mismo, principalmente sobre el terreno local ${ }^{3}$. Sin embargo, han sido los comicios legislativos celebrados entre el 15 y el 18 de enero de 1869 los que han suscitado un mayor interés, considerados por Gutiérrez Lloret y Zurita como

\footnotetext{
${ }^{1}$ Los contenidos del decreto en: Gaceta de Madrid, 10-11-1868.

2 Miguel Martínez Cuadrado, “La elección general para las Cortes Constituyentes de 1869", Revista de Estudios Politicos, n 132, 1963, pp. 65-102.

3 Miguel Martínez Cuadrado, Elecciones y partidos politicos en España (1868-1931), Taurus, Madrid, vol. 1, 1969, pp. 61-90; Pere Anguera, Propaganda politica i processos electorals al Baix Camp, 1869-1873, Associació d'Estudis Reusencs, Reus, 1985; Diego Caro Cancela, Burguesía y jornaleros. Jerez de la Frontera en el sexenio democrático (1868-1874), Caja de Ahorros de Jerez, Jerez, 1990; Eloy Arias, "Expectativas y limitaciones de la democracia en la Sevilla del Sexenio (1868-1874)", Espacio, Tiempo y Forma. Serie V. Historia Contemporánea, t. 3, 1990, pp. 65-84; Rafael Villena, El Sexenio Democrático en la provincia de Ciudad Real. Economía, politica y sociedad (1868-1874), Servicio de Publicaciones de la Universidad de Castilla-La Mancha, Cuenca, 1997, pp. 443-520; César Layana: "Las elecciones generales del Sexenio Democrático en Navarra", Huarte de San Juan. Geografía e Historia, no 7, 2000, pp. 195-246; Rosa María Sepúlveda y Manuel Requena: "Elecciones a Cortes en Albacete durante el Sexenio Democrático", Al-Basit: Revista de estudios albacetenses, $\mathrm{n}^{\circ}$ 44, 2000, pp. 215-233; Marició Janué, Els politics en temps de revolución: la vida politica a Barcelona durant el sexenni revolucionari (1868-1873), Eumo, Vic, 2002; Eduardo González Lorente, Libertad o Religión. Pamplona en el Sexenio Democrático (18681876), Universidad Pública de Navarra, Pamplona, 2008, pp. 169-319 y Antonio Cantero: "Elecciones, partidos politicos y representación parlamentaria de Córdoba en las Cortes Constituyentes de 1869-1871”, Revista Anahgramas, n², 2016, pp. 296-333.
} 
un inequívoco punto de inflexión dentro de los regímenes liberales de la España del siglo $\mathrm{XIX}^{4}$.

Se conocen bien las características que presentaron dichas elecciones. Entre ellas cabrian destacar sus cargas de excitación e intensidad, medidas sobre la base de campañas en las que monárquicos, carlistas y, sobre todo, republicanos pusieron en liza algunos de los elementos definitorios de una vida politica amplificada. Se crearon juntas, clubes, círculos, comités y centros electorales con el objetivo de ganar las adhesiones de masas sociales que por primera vez acudian a las urnas. Se celebraron mitines en los que las élites políticas explicaron conceptos básicos ligados con los derechos individuales y colectivos que traía la Revolución. Se publicaron manifiestos en los que se consignaron los principios democráticos fundamentales, difundidos por una prensa ideologizada que entró en un estado de efervescencia. $Y$ finalmente, no faltaron las convocatorias de manifestaciones ciudadanas en las que las formaciones políticas pugnaron por la conquista del espacio público. Asimismo, los estudios realizados desde una perspectiva local han enriquecido el conocimiento sobre aspectos intrínsecos de la cita electoral. La correlación de las campañas de propaganda politica con lo acontecido en las jornadas de votación y con los escrutinios finales ha posibilitado el desarrollo de interpretaciones que han incidido en la organización de los partidos, en los procesos por los que aquellos llevaron a cabo la formación de candidaturas, en los destacados niveles de participación popular, en la trascendencia que pudo tener en los escrutinios la influencia oficial que pudo jugar el Gobierno Provisional y en la extensión del fraude y la coacción 5 .

El conocimiento sobre el escenario electoral y de lucha política de 1869 es, en definitiva, prolijo. Sin embargo, no es un frente temático cerrado, en la medida en

4 Rosa Ana Gutiérrez Lloret y Rafael Zurita, "Canvi politic i mobilització electoral en la revolución del 1868", Recerques, n 39, 1999, p. 44.

5 Ángel Bahamonde, "Contribución al estudio del fraude electoral en un distrito urbano. Las elecciones de 1869 en Madrid", Hispania, vol. 36, $\mathrm{n}^{\circ}$ 134, 1976, pp. 639-662; Maria de la Concepción Marcos del Olmo, "Las elecciones legislativas de 1869 en la provincia de Valladolid", Investigaciones históricas: Época moderna y contemporánea, $\mathrm{n}^{\circ}$ 5, 1985, pp. 215-252; Mikel Urquijo, "Las elecciones a Cortes Constituyentes de 1869 en Bizkaia", Cuadernos de Sección. Historia y Geografia, $\mathrm{n}^{\circ}$ 19, 1992, pp. 227-246; Rafael Serrano, La Revolución de 1868 en Castilla y León, Servicio de Publicaciones de la Universidad de Valladolid, Valladolid, 1992; Rosa Monlleó, La Gloriosa en Valencia (1864-1869), Alfons el Magnánim, Valencia, 1996, pp. 177-241; Gregorio de la Fuente, "Élite politica y clientelismo durante el Sexenio Democrático (1868-1874)", en Antonio Robles (comp.), Politica en penumbra. Patronazgo y clientelismo políticos en la España contemporánea, Siglo XXI, Madrid, 1996, pp. 133-168; Carmen Pérez Roldán, El Partido Republicano Federal (1868-1874), Endymion, Madrid, 2001; Rosa Ana Gutiérrez Lloret, "Sociabilidad politica, propaganda y cultura tras la revolución de 1868: Los clubes republicanos en el Sexenio Democrático", Ayer, n 44, 2001, pp. 151-174; Antonio Fernández García, "El estreno del sufragio universal en Madrid (1869)", Cuadernos de Historia Contemporánea, $\mathrm{n}^{\circ}$ extraordinario 2003, pp. 71-83; Sergio Sánchez Collantes, Demócratas de antaño. Republicanos y republicanismos en el Gijón decimonónico, Trea, Gijón, 2007, pp. 80-86; Eloy Arias, La Revolución de 1868 en Sevilla, Ayuntamiento de Sevilla, Sevilla, 2010, pp. 316-354; Cecily Hennessy, La República Federal en España. Pi i Margall y el movimiento republicano federal, 1868-1874, Catarata, Madrid, 2010 [1967]; Alexandre Dupont, "Una politización paradójica. Carlismo, democracia e implicación popular durante el Sexenio Democrático", Investigaciones Históricas. Época moderna y contemporánea, $\mathrm{n}^{\circ}$ 37, 2017, pp. 40-68; Diego Caro Cancela (ed.), La revolución de 1868 en Andalucia, Peripecias Libros, Madrid, 2018; Eduardo Higueras, "Radicales contra carlistas: la lucha por el espacio público en Cuenca durante el Sexenio Democrático", Revista de Historia Constitucional, $\mathrm{n}^{\circ}$ 20, 2019, pp. 59-88. 
que su documentación, siguiendo las palabras de Serrano García, no ha sido lo suficientemente explotada ${ }^{6}$. Bajo nuestro punto de vista, no se han aportado suficientes respuestas a interrogantes claves para entender un contexto de iniciación política como aquel. El primero de ellos tiene que ver con los criterios que rigieron la organización de los comicios. La implementación del sufragio universal supuso un desafio para el Gobierno Provisional y, sobre todo, para los poderes locales de la nación. Los Ayuntamientos quedaron consagrados a hacer votar a casi cuatro millones de ciudadanos en gran medida privados del sufragio durante la etapa política precedente. La creación de un cuerpo electoral ampliado exigió la articulación de culturas técnicas ausentes o escasamente desarrolladas. Ante todo, urgió la formulación de un proceso burocrático que acreditara la nueva condición del ciudadano-elector, sustitutiva del credo que había definido el sufragio como un fideicomiso limitado a los individuos que se tipificaban como más interesados en la preservación del orden social ${ }^{7}$. Dentro de ese escenario, se antoja necesario ponderar la importancia de dos aspectos. Por un lado, el papel que desempeñaron las corporaciones municipales, por ser las que, en definitiva, y siguiendo las interpretaciones de Gantús y Salmerón, actuaron como bisagras entre la estructura social local y el mundo de la politica oficial ${ }^{8}$. Y por otro lado, la eficiencia y la efectividad que los Ayuntamientos, en conjunción con el Gobierno, mostraron a la hora de garantizar la extensión social del voto. Una cuestión sobre la que ya se han hecho trascendentales aportaciones para contextos similares al español en el caso europeo, y principalmente en lo que respecta a Francia, tras la aprobación del sufragio universal masculino que siguió a la revolución de $1848^{9}$.

El segundo interrogante que responder estaría relacionado con la relevancia que tuvieron ciertas figuras del nuevo orden politico actuando como árbitros y mediadores del sufragio. En el caso de las principales ciudades españolas, tales funciones fueron principalmente ejercidas por los presidentes y secretarios escrutadores de las mesas de los colegios electorales ${ }^{10}$. El análisis de su

6 Rafael Serrano, "La historiografía en torno al Sexenio 1868-1874: entre el fulgor del centenario y el despliegue sobre lo local”, Ayer, n44, 2001, pp. 18-19.

7 María Sierra, María Antonia Peña y Rafael Zurita, Elegidos y elegibles. La representación parlamentaria en la cultura del liberalismo, Madrid, Marcial Pons, 2010.

8 Fausta Gantús y Alicia Salmerón, "Un acercamiento a las elecciones del México del siglo XIX”, Revista Historia y Memoria, ${ }^{\circ} 14,2017$, pp. 43-44.

9 Véanse especialmente los recientes análisis de: Vincent Villette, Apprendre à voter sous la Ile République. Le suffrage de masse dans le département de la Seine, 1848-1851, Les Indes Savantes, Paris, 2013 y Christophe Voilliot, Le Département de l'Yonne en 1848. Analyse d'une séquence électorale, Éditions du Croquant, Vulaines-sur-Mer, 2017. Sus aproximaciones son deudoras de otros trabajos que han incidido en visiones socio-históricas del voto, como los de: Raymond Huard, Le suffrage universel en France (1848-1946), Aubier, Paris, 1991; Alain Garrigou, Le vote et la vertu. Comment les Français sont dévenus électeurs, Presses de Sciences Po, Paris, 1992; Michel Offerlé, Un homme, une voix? Histoire du suffrage universel, Gallimard, Paris, 1993; Olivier Ihl, "Une ingénierie politique. Augustin Cauchy et les élections du 23 avril 1848", Genèses, n' 49-4, 2002, pp. 4-28; Philippe Tanchoux, Les procédures electorales en France de la fin de l'Ancien Régime à la première Guerre Mondiale, CTHS, Paris, 2004; Yves Déloye y Olivier Ih1, L'Acte de vote, Presses de la Fondation National de Sciences Politiques, Paris, 2008 y Laurent Le Gall, L'Électeur en campagnes dans le Finistère. Une Seconde République de Bas-Bretons, Les Indes Savantes, Paris, 2009.

10 La relevancia de las mesas electorales y su influencia sobre el comportamiento de los votantes en: Alfredo Joignant, "Le bureau de vote et l'invention du citoyen-électeur au Chili à la fin du xixe siècle”, Genèses, $\mathrm{n}^{\circ}$ 49-4, 2002, pp. 29-47. El análisis de las actas tramitadas por las 
extracción social y de sus precedentes ideológicos (ejercicio metodológico representativo en distintos estudios sobre el Sexenio) ${ }^{11}$, permite averiguar qué ciudadanos fueron los partícipes de la nueva vida politica, pero también entender cómo operaron en el marco de un ejercicio del sufragio que en muchas ocasiones se caracterizó por la espontaneidad y qué capacidad de movilización del voto evidenciaron en los espacios en los que actuaron, sirviéndose del capital social acumulado en términos comunitarios.

Finalmente, un tercer interrogante guarda relación con la práctica de la política a ras de suelo en el nuevo escenario democrático, centrada en los propios electores. $\mathrm{Su}$ intervención en los comicios generales debe analizarse por vías que superen los análisis realizados sobre la base de grandes agregados para tomar unidades de observación más amplias, vehiculadas sobre la base del barrio al que pertenecían. La unidad analítica del barrio, coincidente con el entorno socio-comunitario del elector, permite aproximarse a los criterios que pudieron guiar no sólo su inclinación por las candidaturas políticas que se presentaron en los comicios, sino su grado de movilización en los mismos. Ambos comportamientos, no siempre relacionados con los juegos de alta politica, sino también con lazos de solidaridad, relaciones sociales y tejidos políticos preexistentes ${ }^{12}$, resultaban disimiles según el espacio que, residencialmente hablando, se ocupaba en la ciudad ${ }^{13}$.

El propósito de este artículo será arrojar luz sobre los tres interrogantes precedentes a partir del caso de estudio que representa la ciudad de Madrid. Pese al conocimiento que ya se tiene sobre la evolución de las elecciones en la capital española, se antoja necesaria una relectura de las fuentes que sirvieron para su convocatoria, aplicando las interpretaciones de Michel Offerlé ${ }^{14}$. Dicha relectura, desarrollada sobre la base de las actas electorales, las listas de votantes y los libros-registros de electores y combinada con la utilización de la documentación

mesas también ha demostrado su utilidad a la hora de interpretar la participación, la abstención y la movilización electoral en la Revolución Francesa, como se evidencia en: Patrice Gueniffey, La Revolución Francesa y las elecciones. Democracia y representación a fines del siglo XVIII, FCE, México, 2001.

11 Gregorio de la Fuente, Revolución liberal y élites revolucionarias en España (1868-1869), Universidad Complutense, Madrid, 1993 y Marició Janué, "Los representantes políticos de Barcelona durante el Sexenio Democrático (1868-1874): cambio político y continuidad", Historia Contemporánea, $\mathrm{n}^{\circ}$ 13-14, 1996, pp. 251-265.

12 Alain Garrigou, Le vote et la vertu..., op. cit., pp. 21-24.

13 Nos servimos aquí de la importancia de interpretar la experiencia del sufragio considerando la situación de los votantes en su contexto, para así ligar sus conductas no sólo con el mundo político, sino también con el sociológico y el cultural. Sobre esta cuestión, véase el estudio clásico de: Kevin Cox, "The voting decision in a spatial context", Progress in Geography, $\mathrm{n}^{\circ} 1,1969$, pp. 81118. En adición, sirvan los trabajos plena o parcialmente orientados al siglo XIX de: Frank O'Gorman, "The Culture of Elections in England. From the Glorious Revolution to the First World War, 1688-1914", en Eduardo Posada-Carbó (ed.), Elections before democracy: The History of Elections in Europe and Latin America, MacMillan, London, 1996, pp. 17-32; Hilda Sábato, La politica en las calles. Entre el voto y la movilización. Buenos Aires, 1862-1880, Sudamericana, Buenos Aires, 1998; Marcela Ternavasio, La revolución del voto. Política y elecciones en Buenos Aires, 1810-1852, Siglo XXI, Madrid, 2002; Antonio Annino, "El voto y el desconocido siglo XIX", Revista Istor, $\mathrm{n}^{\circ}$ 17, 2004, pp. 43-59 y Fausta Gantús (coord.), Elecciones en el México del siglo XIX. Las prácticas. Tomo I, Instituto Mora, México, 2016.

${ }_{14}$ Michel Offerlé, "De l'histoire électorale à la socio-histoire des électeurs", Romantisme, $\mathrm{n}^{\circ}$ 135-1, 2007, pp. 61-69. 
del Ayuntamiento de Madrid y de la prensa, permitirá conocer nuevos aspectos sobre las técnicas, las prácticas y las pautas sociales que incidieron en el acto del voto a comienzos del Sexenio.

\section{LA COMPLEJA ARTICULACIÓN DE UNA PARTICIPACIÓN ELECTORAL SOCIALMENTE EXTENDIDA}

La trascendencia de los comicios legislativos celebrados entre el 15 y el 18 enero de 1869 está fuera de toda duda desde un punto de vista histórico. Su convocatoria respondió a un objetivo concreto: determinar el modelo político por el que se articularía el Estado tras los episodios revolucionarios de septiembre de 1868, el derrocamiento de Isabel II y la formación del Gobierno Provisional ${ }^{15}$. Ante un acontecimiento tan decisivo, la población debía tener esclarecida su misión al acudir a las urnas. Las premisas sobre las que sostendría su participación se hicieron explicitas desde un primer momento, a través de mítines y difusión de programas politicos. La disyuntiva era evidente. O bien se votaría por una Constitución con rey y Cortes, o bien por un régimen republicano basado en la soberanía popular exclusiva.

Lo que se decidía en la señalada cita con las urnas y la legitimidad que debía presentar el proceso constituyente abierto tras aquella conllevaban una exigencia específica para las autoridades: incrementar el ejercicio del voto con respecto a los comicios municipales celebrados entre el 18 y el 21 de diciembre de 1868. El decreto sobre el sufragio universal masculino se habia aplicado por primera vez en el marco de esas elecciones, entendidas como ensayo del nuevo derecho politico ${ }^{16}$. Para el caso de Madrid que aquí nos atañe, dejaron unos signos de improvisación organizativa que resultaron de inequívoca lección para la organización electoral de enero de 1869. Esos signos no estuvieron relacionados con la creación de una nueva cartografia electoral, proceso que, salvando las dificultades que existieron para habilitar locales en espacios periféricos escasamente urbanizados, se llevó a cabo de una forma eficiente. Para facilitar el voto y disciplinar los flujos de individuos hacia las urnas se proporcionó a las secciones electorales una racionalidad geográfica, estableciéndose una correspondencia entre aquellas y los cien barrios en que se dividía la ciudad, a razón de diez por distrito ${ }^{17}$. En realidad, los verdaderos problemas que entrañó la creación de un electorado de masas se advirtieron en los mecanismos diseñados para garantizar la extensión social del sufragio, que en la capital española dejó estar restringido a las 12.471 personas que en 1867 cumplian con los requisitos económicos e intelectuales

15 Rosa Monlleó, "Republicanos contra monárquicos. Del enfrentamiento electoral y parlamentario a la insurrección federal de 1869", Ayer, n 44, 2001, pp. 55-62.

16 Marició Janué, "Les primeres eleccions municipals amb sufragi universal a Barcelona (18-21 desembre 1868)", III Congrés d'Història de Barcelona. Vol. III, Ajuntament, Barcelona, 1993, pp. 465-474 y "Autor", 2017.

17 De manera anterior a la aprobación del sufragio universal masculino, Madrid presentaba una sección electoral por distrito. Al generar una correspondencia entre sección electoral y barrio, el Ayuntamiento de Madrid aludió a la necesidad de establecer la división más apropiada, cómoda y útil para los actos del vecindario. La selección de los locales que sirvieron como colegios para las votaciones quedó en manos de los alcaldes de barrio, los cuales priorizaron la utilización de centros de instrucción pública, academias e instituciones administrativas locales y estatales, sirviéndose también de recintos hospitalarios, sacristías, iglesias, tiendas y almacenes. En: Archivo de Villa, Secretaria (AVM-S), Bando del Ayuntamiento Popular de Madrid sobre elecciones municipales del 23 de noviembre de 1868, signatura (sig.) 4-406-13 y AVM-S, Circulares y oficios sobre elecciones en Madrid, 1868-1869, sig. 5-332-8. 
exigidos para votar en la Ley Electoral de $1865^{18}$ para alcanzar a los 76.095 individuos que superaban los veinticinco años a finales de 1868.

En virtud de lo dispuesto en el decreto sobre el ejercicio del sufragio universal masculino, los documentos que sirvieron como identificadores para los electores fueron las cédulas de vecindad. Para su elaboración, se utilizaron como matrices los Padrones de Habitantes, básicos para discernir si un individuo tenía cualidades politicas. La sección de Estadística del Ayuntamiento de Madrid fue la encargada de formalizar esa operación, quedando los alcaldes de barrio como responsables del reparto de las cédulas a domicilio ${ }^{19}$. De las 76.095 que se imprimieron quedaron sin distribuir 25.386. De estas últimas, más de un $90 \%$ quedaron sin reclamar en el plazo que el consistorio estableció para ello (7 al 16 de diciembre de 1868) ${ }^{20}$. Durante las jornadas de votación, un importante número de habitantes de los barrios populares no pudieron ejercer su derecho recién estrenado, al no acudir a los colegios con sus documentos identificativos ${ }^{21}$.

\section{Gráfico 1. División de Madrid por distritos (izquierda) y barrios (derecha) con indicación de colegios electorales en los comicios municipales de diciembre de 1868}
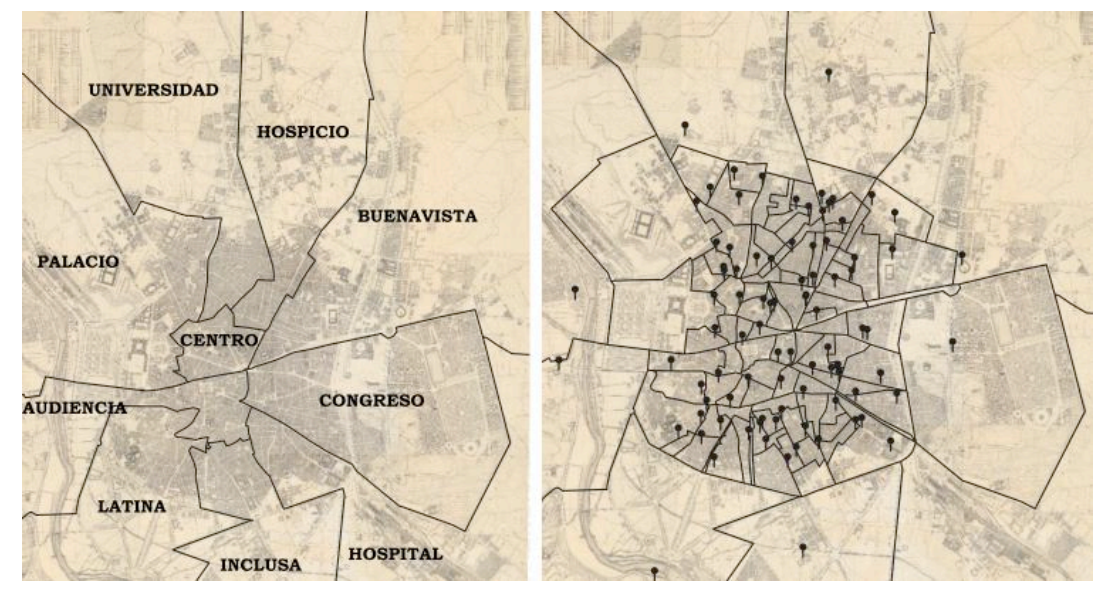

Elaboración propia sobre el Plano de Madrid formado por el Instituto Geográfico y Estadístico bajo la dirección de Carlos Ibáñez e Ibáñez de Íbero (1872-1874).

18 Con anterioridad a la aprobación del sufragio universal masculino, la condición de elector se regía por una cosmovisión liberal dirigista, siguiendo los términos de Sierra, Peña y Zurita, que circunscribía la ciudadanía política a la lógica de la propiedad, la riqueza y las competencias intelectuales. Para el caso español, el ejercicio del sufragio quedaba restringido a quienes acreditasen el pago de una cuota minima de 20 escudos anuales por concepto de subsidio territorial o industrial y a quienes formaran parte del conjunto de las llamadas capacidades. Véase: María Sierra, María Antonia Peña y Rafael Zurita, Elegidos y elegibles: la representación parlamentaria en la cultura del liberalismo, Marcial Pons, Madrid, 2010. Para una comparativa con el caso europeo, véanse: Pierre Rosanvallon, Le sacre du citoyen. Histoire du suffrage universel en France, Gallimard, Paris, 1992 y Alan S. Kahan, Liberalism in Nineteenth-Century Europe: The political culture of limited suffrage, Palgrave, Basingstoke, 2003, pp. 1-65.

19 Sobre la importancia que para la historiografia ofrece la documentación producida por los municipios en las citas electorales, véase: Fausta Gantús (coord.), Elecciones en el México del siglo XIX. Las fuentes, Instituto Mora, México, 2015.

20 AVM-S, Bando del Ayuntamiento Popular de Madrid sobre organización de la consulta electoral del 18 al 21 de diciembre de 1868, sig. 4-406-20.

21 AVM-S, Libro de Actas del Ayuntamiento de Madrid (LAAM), sesión del 27 de diciembre de 1868. 
La gran cantidad de cédulas que quedó sin repartir no pasó desapercibida para la prensa. Para la republicana, el problema de los repartos se explicaba por la escasa publicidad que el consistorio habia dado al nuevo sistema electoral (mediante edictos que advirtieran de sus características) y por la praxis supuestamente arbitraria seguida por los alcaldes de barrio en la entrega de las identificaciones ${ }^{22}$. Algunos rotativos llegaron a exigir que se abriera causa judicial contra esas autoridades y se declararan nulas las elecciones, considerando que el consistorio saliente de las mismas no era la "verdadera expresión de la voluntad del cuerpo electoral"23. Por el contrario, los periódicos progresistas asociaron la exigua participación en los comicios a la conducta poblacional. A su juicio, ni el consistorio ni los alcaldes de barrio eran responsables de que los vecinos no hubieran querido aprovechar la posibilidad de actuar como "ciudadanoselectores" o de "tomarse la molestia de reclamar cualquier equivocación" en los dias que se habilitaron para recuperar las cédulas no recibidas ${ }^{24}$.

\section{Tabla 1. Expedición y reclamación de cédulas de vecindad en las elecciones municipales de diciembre de 1868}

\begin{tabular}{|c|c|c|c|c|c|}
\hline Distrito & Electores & $\begin{array}{c}\text { Cédulas } \\
\text { electorales } \\
\text { no } \\
\text { entregadas }\end{array}$ & $\begin{array}{c}\text { Cédulas no } \\
\text { entregadas } \\
\text { sobre total de } \\
\text { electores (\%) }\end{array}$ & $\begin{array}{c}\text { Cédulas no } \\
\text { reclamadas }\end{array}$ & $\begin{array}{c}\text { Cédulas no } \\
\text { reclamadas } \\
\text { sobre total } \\
\text { de no } \\
\text { entregadas } \\
\text { (\%) }\end{array}$ \\
\hline Audiencia & 7.214 & 1.954 & $27,09 \%$ & 1.714 & $87,72 \%$ \\
\hline Buenavista & 6.499 & 2.133 & $32,82 \%$ & 1.935 & $90,72 \%$ \\
\hline Centro & 6.382 & 1.418 & $22,22 \%$ & 1.179 & $83,15 \%$ \\
\hline Congreso & 7.187 & 2.143 & $29,82 \%$ & 1.935 & $90,29 \%$ \\
\hline Hospicio & 6.889 & 2.496 & $36,23 \%$ & 2.320 & $92,95 \%$ \\
\hline Hospital & 8.040 & 3.037 & $37,77 \%$ & 2.830 & $93,18 \%$ \\
\hline Inclusa & 8.806 & 3.556 & $40,38 \%$ & 3.383 & $95,13 \%$ \\
\hline Latina & 9.354 & 3.580 & $38,27 \%$ & 3.429 & $95,78 \%$ \\
\hline Palacio & 7.149 & 2.595 & $36,30 \%$ & 2.337 & $90,06 \%$ \\
\hline Universidad & 8.575 & 2.474 & $28,85 \%$ & 2.283 & $92,28 \%$ \\
\hline Total & $\mathbf{7 6 . 0 9 5}$ & $\mathbf{2 5 . 3 8 6}$ & $\mathbf{3 3 , 3 6 \%}$ & $\mathbf{2 3 . 3 4 5}$ & $\mathbf{9 1 , 9 6 \%}$ \\
\hline
\end{tabular}

Fuente: AVM-S, actas de las elecciones municipales de 1868, sigs. 4-444-1 a 4-456-2.

Más allá de lo que esgrimiera la prensa, la enorme cantidad de cédulas que quedaron sin repartir en las oficinas del Ayuntamiento podría explicarse por un factor concreto: el Padrón Municipal de Habitantes que sirvió como guía para la elaboración de esos documentos. La imposibilidad de realizar uno nuevo para cerca de 300.000 personas en tan corto periodo de tiempo (menos de un mes entre la publicación del decreto sobre el ejercicio del sufragio universal y el inicio de las primeras tareas electorales) llevó a utilizar el formalizado el 1 de enero de 1868. Teniendo en cuenta la elevada movilidad residencial de una época en la que el asentamiento se basaba casi integramente en el alquiler, se perdian de vista los electores que hubiesen cambiado de vivienda. Junto a ellos, resultaban

22 La Igualdad, 4-12-1868 y La Discusión, 11-12-1868.

23 El Amigo del Pueblo, 21-12-1868.

24 Las Novedades, 20-12-1868 y La Iberia, 23-12-1868. 
susceptibles de quedar omitidos muchos de los que habian regresado a la ciudad con el triunfo de la Revolución, tras emigrar por motivos políticos ${ }^{25}$.

La improvisación de la organización técnica electoral podía pasarse por alto en el ensayo de diciembre de 1868, pero no en unos comicios generales que dilucidaban la direccionalidad de la Revolución. Antes de remitir el escrutinio final de las elecciones municipales, la Junta Provincial Electoral de Madrid envió una circular al Ayuntamiento de la capital expresando la necesidad de acometer tareas urgentes para cubrir los vacíos organizativos advertidos en aquellos. E1 más importante guardaba precisamente relación con el reparto de las cédulas. El objetivo en lo que respecta a dicho proceso era elaborar nuevos documentos identificativos ajustados a los datos contenidos en un nuevo Padrón Municipal de Habitantes, que se estaba ultimando a finales de diciembre. Ángel Fernández de los Ríos, recientemente elegido concejal y uno de los principales firmantes de la circular, hizo constar las limitaciones que habian existido para el ejercicio del voto tras haber quedado sin la acreditación justificativa de tal derecho "miles de ciudadanos que se habian desplazado a otros barrios y distritos" desde su empadronamiento el 1 de enero de 1868. Además, consignó la necesidad de perfeccionar los trabajos de los alcaldes de barrio y de extremar su rigurosidad al investigar los traslados residenciales ${ }^{26}$.

Nicolás María Rivero, alcalde de Madrid, respondió a la anterior circular de manera ambivalente. Por un lado, defendió la rigurosidad de los trabajos del consistorio y los alcaldes de barrio en el reparto de las cédulas. A su juicio, el hecho de que la población no se hubiera valido de su derecho electoral de una manera extendida estaba relacionado con "costumbres no susceptibles de desarraigar en el escaso tiempo que se llevaba practicando la libertad". Ahora bien, Rivero también era consciente de que la emisión del voto debía amplificarse. $\mathrm{Y}$ para conseguirlo, tenían que ponerse en liza "todos los remedios posibles y todas las vias de publicidad" al alcance del Ayuntamiento de Madrid27.

Las opiniones vertidas desde la Junta Provincial Electoral de Madrid para fortalecer la legitimidad del sistema recién estrenado fueron tajantes. Dándose por hecho que las cédulas utilizadas para las elecciones municipales debian actualizarse para las legislativas, también se entendió que el consistorio tenía que crear mecanismos más efectivos para su entrega. Las soluciones que para ello se propusieron fueron dos. La primera pasaba por la creación de cien comisiones distribuidas en otras tantas secciones electorales que Madrid tenía en ese momento, a razón de una por barrio. En esas comisiones se integrarían cuatro electores elegidos al azar por los concejales del Ayuntamiento en sesión plenaria $^{28}$, siendo su misión la de cooperar con los alcaldes de barrio en el reparto de las cédulas. La segunda solución que se puso sobre la mesa se relacionaba con la posibilidad de extender el período temporal fijado para la

25 Autor, 2017.

26 AVM-S, Circular de la Junta Provincial Electoral de Madrid al Ayuntamiento de Madrid, 23 de diciembre de 1868, sig. 5-332-8.

27 AVM-S, Comunicación del alcalde popular de Madrid, D. Nicolás María Rivero, a la Junta Provincial Electoral de Madrid, 29 de diciembre de 1868, sig. 5-332-8.

28 La elección de las comisiones en: AVM-S, LAAM, sesión del 6 de enero de 1869. 
distribución de las mismas cédulas, de cara a prolongarlo con respecto al de las elecciones municipales ${ }^{29}$.

Las preocupaciones mostradas por el Ayuntamiento de Madrid conectaron con las posteriormente expresadas por el Gobierno Provisional. Los comicios locales habían demostrado que, con el establecimiento de la libertad de prensa, los diarios aprovechaban la mínima ocasión que se les presentaba para discutir la imparcialidad de las consultas, ligándolas en no pocos casos con irregularidades en la entrega de las cédulas. No fue así casual la publicación de un decreto del Ministerio de Gobernación el 30 de diciembre de 1868 dictando varias disposiciones complementarias para el ejercicio del sufragio universal en las inminentes elecciones generales. En aquel se acordaba la repartición de nuevas cédulas sobre la base del nuevo padrón de habitantes y la formación de las mencionadas comisiones para coadyuvar a los alcaldes de barrio en su distribución a domicilio, estableciéndose para ello un plazo de nueve días entre el 5 de enero y la medianoche del día en que comenzaban las votaciones ${ }^{30}$.

Las nuevas medidas del Ministerio de la Gobernación se consideraron relevantes, pero no lo suficientemente decisivas como para garantizar la extensión social del voto. El principal problema que se advertía tenía que ver con el hecho de que no se dictaminaba un plazo por el que los votantes pudieran reclamar sus cédulas no obtenidas en los repartos ${ }^{31}$. Para La Época, urgía facilitar las apelaciones, sobre todo si se tenía en cuenta que en aquel momento no se imprimian o publicaban listas electorales con carácter oficial. De esta forma, al futuro votante no le quedaba otro medio de averiguar su derecho "que el de esperar en su casa a que le lleven la cédula"32. En similares términos se expresaron El Imparcial y La Igualdad, considerando que las disposiciones complementarias del Ministerio de la Gobernación no desactivarían las posibles negligencias que pudieran cometer los alcaldes de barrio "negando las cédulas a determinados vecinos", ni para las que pudieran ocasionar las comisiones por causa de posibles "compadrazgos o entendimientos con las autoridades municipales"33.

En tales condiciones, se hicieron necesarias nuevas aclaraciones sobre el ejercicio del voto por parte del Ministerio de la Gobernación, publicadas el 6 de enero de 1869. Para facilitar unas apelaciones que se consideraban como de inexorable presencia en todas las leyes electorales, se dictaminaron varias medidas. La primera de ellas tuvo que ver con la obligatoriedad de colocar en las puertas de los colegios de las secciones electorales las listas certificadas de los vecinos que debian votar en las mismas tres dias antes del comienzo de las elecciones (12 de enero). Todos los que no figurasen en ellas podrian reclamar en cualquier momento ante el alcalde de barrio o ante la comisión encargada de distribuir las cédulas su derecho electoral, recibiendo un certificado con el visto bueno de cualquiera de esos individuos una vez se corroborase su inscripción en el padrón. En segundo término, se expresó el derecho de los vecinos a consultar

29 Fijado entre el 1 y el 6 de diciembre de 1868. En: AVM-S, sig. 5-332-8.

30 Gaceta de Madrid, 30-12-1868.

31 La Iberia, 31-12-1868.

32 La Época, 31-12-1868.

33 El Imparcial, 31-12-1868 y La Igualdad, 3-1-1869. 
el censo de cada distrito en las secretarias de los Ayuntamientos durante el periodo inmediatamente anterior a los comicios. Y, finalmente, se dispuso que, si bien las cédulas electorales no distribuidas entre el 5 y el 14 de enero de 1869 quedarían bajo custodia del consistorio, todos aquellos vecinos que no estuvieran en posesión de las mismas en el momento de su llegada a los colegios tendrían la oportunidad de solicitarlas in situ. En este último caso, la acreditación de la identidad del elector quedaría probada siempre y cuando fuera reconocido por dos vecinos del barrio presentes en el colegio de la sección electoral a la que se adscribia ${ }^{34}$.

Las autoridades gubernamentales también sacaron lecciones importantes de otros problemas percibidos en las elecciones municipales. Así por ejemplo, se consideró la posibilidad de que algunos electores pudieran extraviar sus cédulas una vez recibidas. La contemplación de esas pérdidas exigió la adopción de medios que no se habían puesto en práctica en los comicios locales, como la concesión de cédulas duplicadas y triplicadas con respecto a las originales. Ahora bien, se estableció un control riguroso sobre las mismas, para evitar cualquier intento de suplantación de identidad en el voto. En las cédulas que se entregaron por segunda o tercera vez se hizo constar este hecho, anotándose posteriormente en listas especiales y en los libros-registros de electores como "cédulas adicionales" para conocer la proporción de papeletas de una y otra tipología en cada barrio.

En lo que respecta a las cédulas y a su reparto, fueron los republicanos los que mostraron un mayor celo en dotar de la mayor eficacia posible a esa operación. A lo que apelaron fue al hecho de que las clases populares contaran con los documentos acreditativos para el voto en la proporción más elevada. Ello explica que, en un esfuerzo final por conseguir que la mayor parte de sus correligionarios pudieran depositar sus papeletas en las urnas, los órganos de prensa republicanos publicaran indicaciones suplementarias para que aquellos pudieran proveerse de cédulas. En el distrito de Palacio se instó a que todos aquellos que por sus ocupaciones no tuvieran tiempo para reclamarlas dejaran por escrito su nombre y las señas de su domicilio en la casa del alcalde de su barrio. Similares advertencias recibieron los votantes republicanos de los distritos de Audiencia, Inclusa y Centro, publicándose listas de los que lideraban las comisiones de reparto de cédulas en barrios con la expresión de sus domicilios ${ }^{35}$.

La influencia de las anteriores disposiciones puede advertirse mediante el análisis pormenorizado de las actas de las elecciones generales de 1869. La influencia de las tareas que se realizaron para mitigar el problema de los repartos fue más o menos significativa, en el sentido en que se consiguió disminuir el número de habitantes sin documento justificativo en casi diez puntos porcentuales con respecto a los comicios municipales. Sin embargo, persistían unas enormes diferencias dentro de ese escenario entre los distritos de Madrid.

\footnotetext{
34 Gaceta de Madrid, 7-1-1869.

35 La Discusión, 14 y 15 de enero de 1869.
} 
Tabla 2. Expedición y reclamación de cédulas de vecindad en las elecciones generales de 1869

\begin{tabular}{|c|c|c|c|c|c|}
\hline Distrito & Electores & $\begin{array}{c}\text { Cédulas } \\
\text { electorales } \\
\text { no } \\
\text { entregadas }\end{array}$ & $\begin{array}{c}\text { Cédulas no } \\
\text { entregadas } \\
\text { sobre total } \\
\text { de electores } \\
\mathbf{( \% )}\end{array}$ & $\begin{array}{c}\text { Cédulas no } \\
\text { reclamadas }\end{array}$ & $\begin{array}{c}\text { Cédulas no } \\
\text { reclamadas } \\
\text { sobre total } \\
\text { de no } \\
\text { entregadas } \\
\text { (\%) }\end{array}$ \\
\hline Audiencia & 7.670 & 2.108 & $27,48 \%$ & 2.026 & $96,11 \%$ \\
\hline Buenavista & 6.824 & 1.442 & $21,13 \%$ & 846 & $58,67 \%$ \\
\hline Centro & 6.885 & 1.013 & $14,71 \%$ & 392 & $38,70 \%$ \\
\hline Congreso & 7.321 & 1.300 & $17,76 \%$ & 980 & $75,38 \%$ \\
\hline Hospicio & 7.786 & 2.320 & $29,80 \%$ & 2.200 & $94,83 \%$ \\
\hline Hospital & 8.701 & 1.958 & $22,50 \%$ & 1.766 & $90,19 \%$ \\
\hline Inclusa & 10.301 & 3.678 & $35,71 \%$ & 3.608 & $98,10 \%$ \\
\hline Latina & 10.561 & 2.680 & $25,38 \%$ & 2.182 & $81,42 \%$ \\
\hline Palacio & 7.139 & 757 & $10,60 \%$ & 610 & $80,58 \%$ \\
\hline Universidad & 9.536 & 2.283 & $23,94 \%$ & 2.109 & $92,38 \%$ \\
\hline Total & $\mathbf{8 2 . 7 2 4}$ & $\mathbf{1 9 . 5 3 9}$ & $\mathbf{2 3 , 6 2 \%}$ & $\mathbf{1 6 . 7 1 9}$ & $\mathbf{8 5 , 5 7 \%}$ \\
\hline
\end{tabular}

Fuente: AVM-S, actas de las elecciones generales de 1869, sigs. 4-456-3 a 4-474-1 y 10-36-42.

Además, las reclamaciones que los electores privados de su derecho podían presentar hasta las doce de la noche del 14 de enero e incluso ya iniciados los comicios en los colegios electorales fueron muy escasas. En el caso de estas apelaciones, también cobró una enorme importancia el abrupto contraste abierto entre unas zonas y otras. En el distrito de Inclusa, de características socioeconómicas netamente populares, todas aquellas cédulas que no pudieron ser entregadas en los domicilios de sus diez barrios permanecieron prácticamente intactas en las oficinas municipales. En los distritos más acomodados, como Buenavista y Centro, no se presentó ese problema a una escala significativa. En el caso del segundo, fueron incluso mayoría los que tuvieron la oportunidad de ejercer el voto tras la oportuna reclamación.

A diferencia de las actas de las elecciones municipales de 1868, las de las generales de 1869 conservan para algunas secciones los documentos que los encargados del reparto de cédulas rellenaron para justificar su devolución. En aras de arrojar luz sobre ese proceso se pueden referenciar los datos correspondientes al barrio de Aguas, que contaba con unas características socioeconómicas populares y que se enclavaba en el distrito de Latina. En la mayoría de los casos, las cédulas no se entregaron como consecuencia de los traslados residenciales verificados por los vecinos. La relevancia de este factor resulta evidente si se analizan las restantes causas de devolución. Al margen de fallecimientos, los alcaldes de barrio alegaban ausencias temporales de vecinos o el desconocimiento de su paradero, lo que podía relacionarse con errores cometidos en la elaboración de los padrones. Una hipótesis que adquiere resonancia teniendo en cuenta que algunos supuestos electores eran individuos con nombre duplicado, menores de edad y presos incapacitados para el voto. 


\section{Gráfico 2. Causas de devolución de cédulas en el barrio de Aguas}

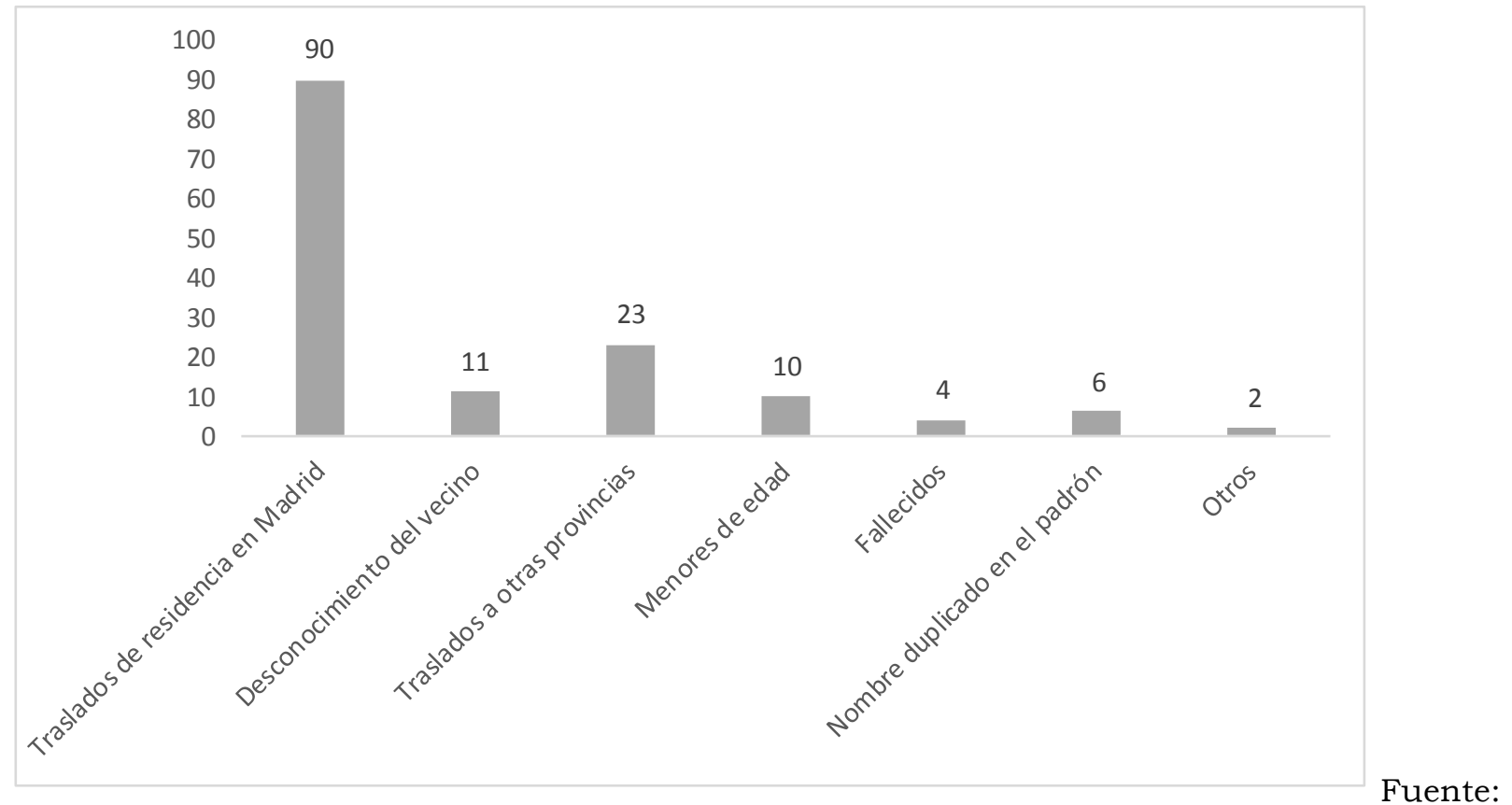

AVM-S, actas de las elecciones generales de 1869, distrito de Latina, sig. 4-470-1.

Los datos anteriormente apuntados son fundamentales a la hora de discernir la participación del vecindario en los comicios generales de enero de 1869. La medición de su retraimiento en las urnas y del grado de voluntariedad en ese proceso se antoja complicada por la elevada proporción de lo que la historiografia francesa ha denominado electores "faux" o "mal inscrits" (inscritos en el padrón de un barrio que fallecieron, que fueron condenados a penas de prisión, que estaban ausentes durante el reparto de las cédulas por motivos laborales o que se desplazaron antes de la votación) ${ }^{36}$. Si, por el contrario, analizamos el ejercicio del sufragio por los habitantes que estaban en disposición de sus documentos identificativos para acudir a las urnas, la tasa de abstención es realmente baja y pondría en entredicho la apatía del electorado popular de los distritos de Latina, Universidad o Inclusa.

36 Charles Edward Merriam y Harold Gosnell, Non-Voting. Causes and methods of control, University of Chicago Press, Chicago, 1924; Alain Lancelot, L'Abstentionnisme electoral en France, Armand Colin, Paris, 1968 y Nonna Mayer, Sociologie des comportements politiques, Armand Colin, Paris, 2014, pp. 178-179. Véanse además las interpretaciones clásicas sobre la abstención forzosa en los procesos electorales de la década de los años veinte del siglo XX en Chicago, realizadas por: Charles Edward Merriam y Harold Gosnell, Non-Voting. Causes and methods of control, University of Chicago Press, Chicago, 1924. 


\section{Gráfico 3. Participación por distritos en las elecciones generales de 1869 en función de la tenencia de cédulas de vecindad}

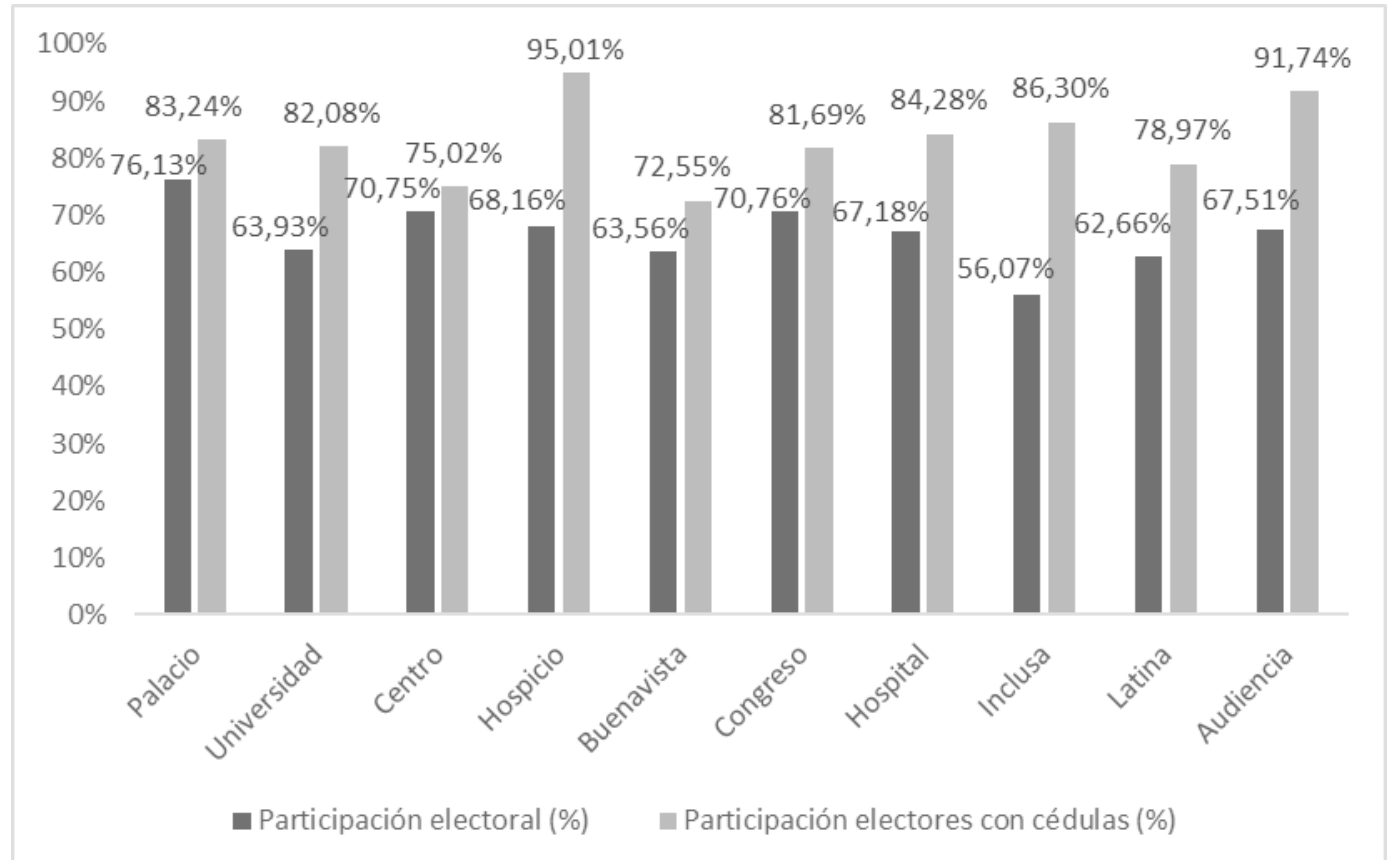

Fuente: AVM-S, actas de las elecciones generales de 1869, sig. 10-36-42.

De este modo, más que de una participación más o menos elevada en las elecciones de 1869, cabría hablar de mayores o menores posibilidades de sus habitantes para quedar habilitados en el ejercicio del voto. A la hora de generar interpretaciones sobre esta cuestión, no deben perderse de vista tres aspectos. Primero, la inexperiencia politica que tenía buena parte de la población y las dificultades que los sectores más humildes debieron atravesar al familiarizarse con el nuevo sistema electoral, valorando sus reducidas capacidades de lectoescritura y su escasa accesibilidad a la información distribuida por la prensa. Segundo, los errores y omisiones cometidos en la entrega de las cédulas y en la actualización del padrón municipal. Y finalmente, las características estructurales de la ciudad ligadas a circunstancias sociales, laborales y demográficas. En un contexto como el de 1869, no sólo resulta necesario valorar la volatilidad de los asentamientos residenciales en el espacio urbano, sobre todo en las zonas más populares ${ }^{37}$, y el hecho de que aquellos escapaban al control de unas autoridades que no los registraban de manera sistemática, como ocurriría después. También se antoja crucial evaluar la densidad que en cada barrio tenían las redes asociativas politicas y civiles y los lazos de conocimiento mutuo vehiculados sobre la lógica de la reciprocidad y la confianza. Aspectos que creaban solidaridades e intereses comunes susceptibles de repercutir en la obtención y la reclamación del voto.

37 La movilidad residencial de Madrid guardaba similitudes con la de las ciudades europeas de esa época. Véanse: Colin G. Pooley y Jean Turnbull, "Changing home and working place in Victorian London: the life of Henry Jaques, shirtmaker”, Urban History, vol. 24, 2, 1997, pp. 148178 y Jean-Luc Pinol, "La mobilité dans la ville, révélateur des sociétés urbaines", Annales de Démographie Historique, $\mathrm{n}^{\circ}$ 1, 1999, pp. 7-16. 


\section{ARBITRAJE, MEDIACIÓN Y MOVILIZACIÓN DEL VOTO EN LOS PRIMEROS EJERCICIOS DEL SUFRAGIO UNIVERSAL}

Cuando la prensa describió el ambiente de Madrid en las elecciones de 1869, destacó la excitación de sus calles y el compromiso de sus habitantes con el disfrute del sufragio universal. Las crónicas que se dedicaron al acontecimiento en el extranjero también recogieron ese estado de cosas. Las del diario The Times fueron las más explícitas. Su corresponsal en la capital describió a los lectores británicos las características del proceso electoral en los colegios. De manera particular, llamó la atención sobre el aspecto de uno de ellos, situado en la Academia de Jurisprudencia de la calle de la Montera, en pleno centro de la ciudad. La institución albergaba la sección electoral del barrio de Caballero de Gracia, en el distrito de Buenavista. En la planta baja se encontraba la mesa electoral. Al dirigirse a su estrado y comentar el encargo que realizaba, el presidente y los cuatro secretarios escrutadores describieron al corresponsal el orden a seguir durante las jornadas de votación. El presidente leería en voz alta los datos de la cédula del votante, los secretarios comprobarian a continuación su nombre en los libros-registros de electores, elaborados a través de los datos del padrón municipal, y los vecinos depositarian finalmente sus papeletas en las urnas, en intervalos de entre uno y cinco minutos ${ }^{38}$.

Para el corresponsal de The Times, la formación de las mesas electorales era uno de los acontecimientos más decisivos de aquellas jornadas, por la influencia que podian tener sobre el escrutinio de cada sección. A su juicio, podían decidir los resultados que más convenían a los intereses de las formaciones politicas en función del control que estas tuvieran sobre su composición ${ }^{39}$. Su votación tuvo lugar el 15 de enero de 1869. El primer día de los comicios generales quedó dedicado a la elección de las cien presidencias y las cuatrocientas secretarias escrutadoras de las cien secciones electorales de Madrid ${ }^{40}$. En lo que respecta a las presidencias, su votación resultaba un acto inédito. Durante la etapa isabelina, $y$ en virtud de la ley electoral de 1865, aquellas quedaban automáticamente asumidas por los mayores contribuyentes. En cada uno de los diez distritos municipales se formaba una lista previa con los nombres de los cinco vecinos que más cantidades económicas sufragaban en concepto de subsidio territorial o industrial, siendo al primero de ellos al que correspondia ejercer el máximo cargo representativo de cada mesa. Si los mencionados contribuyentes no se hallaban presentes al constituirse cada colegio, era el teniente de alcalde del distrito quien actuaba como presidente.

La articulación de las mesas electorales resulta interesante por circunstancias poco exploradas por la historiografia ${ }^{41}$. El análisis de sus presidencias y secretarias escrutadoras resulta clave a la hora de dilucidar las

38 The Times, 21 y 22 de enero de 1869.

39 Ángel Bahamonde, "Contribución al estudio del fraude electoral en un distrito urbano: las elecciones de 1869 en Madrid”, op. cit., pp. 651-654.

40 Una presidencia y cuatro secretarias escrutadoras por cada sección.

41 Si se han hecho aproximaciones de notable calado a la importancia que tuvieron en las elecciones de la Restauración figuras politicas que podían mediar en la emisión del voto a nivel de barrio, como los interventores. En: Carlos Hernández Quero, "El voto de la costumbre. Culturas politicas $y$ crisis urbana en Madrid a comienzos del siglo XX”, Studia Histórica. Historia Contemporánea, $\mathrm{n}^{\circ}$ 35, 2017, pp. 369-403. 
bases sociales que las formaciones politicas tenian en este contexto, los condicionantes profesionales y económicos de sus integrantes y sus precedentes ideológicos. O dicho de otra forma, el estudio de la composición de las mesas permite descubrir quiénes se convirtieron en partícipes directos del nuevo ejercicio político democrático, actuando como bisagras entre los líderes de las candidaturas oficiales de los partidos, elegidos en sus comités centrales, y una extensísima parte de una población que hasta entonces fue tipificada como no apta para ejercer el voto.

El cruzamiento de los nombres de los presidentes y secretarios escrutadores de las mesas electorales con su ocupación, obtenida a partir del Padrón de Habitantes ultimado a finales de 1868, aporta información sobre la extracción social que aquellos presentaban en los inicios del Sexenio. Un 17,6\% de los mismos no registraba en el empadronamiento actividad profesional. Eran cesantes, jubilados y retirados, estudiantes y, sobre todo, propietarios, que declaraban contribuciones muy disimiles por la tenencia de inmuebles. E1 82,4\% restante sí consignaba una dedicación laboral. Casi una tercera parte de este sector estaba formado por trabajadores manuales. Para buena parte de ellos, la participación en las mesas representó la primera oportunidad de intervenir en un proceso político y quizás de iniciar una carrera en ese escenario a nivel local. Más de una cuarta parte no cumplian con los requisitos exigidos para votar en la etapa isabelina, de acuerdo con los datos obtenidos de las listas de electores que sirvieron para organizar los comicios generales celebrados en 1867 en Madrid.

Resulta cierto que existian excepciones remarcables en el anterior escenario. En las listas de electores de 1867 figuraban diamantistas, joyeros y plateros acomodados de barrios del centro como José Sainz Grajeda y Agustín Pinedo (que respectivamente pagaban cuotas anuales de contribución industrial de 163 y 131 escudos por sus establecimientos en las calles del Príncipe y del Arenal); exitosos propietarios de negocios dedicados al procesado de comidas y bebidas, como los tahoneros Andrés Pardeiro y Domingo Garrido o los confiteros Carlos Prast y Antonio Sánchez, y reconocidos profesionales del sector de los tejidos y la confección, como el sastre Juan Sloker. Entre los trabajadores manuales que decidieron involucrarse en la actividad politica tras las jornadas revolucionarias actuando como presidentes o secretarios escrutadores en las mesas predominaban aquellos que ofrecian un cierto grado de especialización en sus oficios (sastres, encuadernadores, impresores, joyeros y plateros, broncistas, etc).

\section{Tabla 3. Extracción socio-profesional de los presidentes y secretarios de las mesas electorales de Madrid en 1869}

\begin{tabular}{|c|c|c|c|c|}
\hline Categoria profesional & $\boldsymbol{N}$ & $\mathbf{\%}$ & $\begin{array}{c}\text { Condición de } \\
\text { elector antes } \\
\text { de 1869 }\end{array}$ & \% \\
\hline Profesionales liberales y técnicos & 69 & 13,8 & 32 & 46,38 \\
\hline Trabajadores administrativos y de gestión & 1 & 0,2 & - & - \\
\hline Oficinistas y funcionarios & 92 & 18,4 & 27 & 29,35 \\
\hline Trabajadores de ventas & 101 & 20,2 & 34 & 33,66 \\
\hline Trabajadores de servicios personales & 13 & 2,6 & - & - \\
\hline Agropecuarios y forestales & 6 & 1,2 & - & - \\
\hline Trabajadores del sector de la producción & 130 & 26 & 31 & 23,85 \\
\hline Propietarios y rentistas & 39 & 7,8 & 12 & 30,77 \\
\hline Cesantes & 24 & 4,8 & 5 & 20,83 \\
\hline
\end{tabular}


VOTAR EN MADRID TRAS LA REVOLUCIÓN DE 1868. TÉCNICAS, PROCESOS...

\begin{tabular}{|c|c|c|c|c|}
\hline Estudiantes & 5 & 1 & - &. \\
\hline Jubilados o retirados & 6 & 1,2 & 4 & 66,67 \\
\hline No indican & 14 & 2,8 & 1 & 7,14 \\
\hline Totales & $\mathbf{5 0 0}$ & $\mathbf{1 0 0}$ & $\mathbf{1 4 6}$ & $\mathbf{2 9 , 2 0}$ \\
\hline
\end{tabular}

Fuente: Archivo de Villa de Madrid, Estadística (AVM-E), Rectificación del Padrón de Habitantes de Madrid de 1868 (PHM), AVM-S, actas de las elecciones generales de 1869, sig. 4-456-3 a 4-

474-1 y AVM-S, listas rectificadas de los electores para diputados a Cortes pertenecientes a Madrid en 1867, sig. 4-302-2.

\section{Gráfico 4. Integrantes de las mesas electorales de Madrid en los comicios generales de 1869, distribuidos según su derecho de voto en 1867}

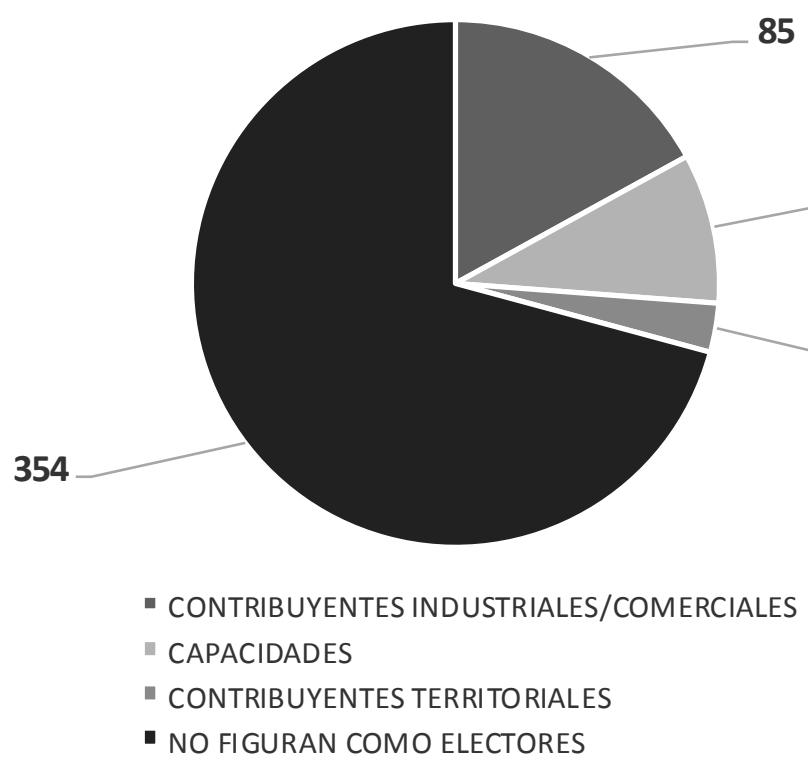

Fuente: AVM-S, actas de las elecciones generales de 1869, sig. 4-456-3 a 4-474-1 y AVM-S, listas de electores para diputados a Cortes en Madrid de 1867, sig. 4-302-2.

Por detrás del anterior sector laboral figuraban representantes de grupos profesionales que, por su situación socioeconómica, podian tener una mayor familiaridad con las características de los procesos electorales de la etapa isabelina. Entre ellos destacaban los patronos de establecimientos comerciales. Algunos de ellos se encontraban en las listas de mayores contribuyentes antes de 1869, como Félix Eguiluz, propietario de un negocio en la calle Mayor por el que pagaba un subsidio de 1.721 escudos anuales o Celestino Ansorena, iniciador de una destacada saga de vendedores de diamantes con tienda ubicada en la calle de Espoz y Mina (815 escudos anuales). Seguian después oficinistas y funcionarios (escribanos y empleados de ministerios o instancias municipales) y profesionales liberales. Entre estos últimos se encontraban abogados, notarios, médicos, farmacéuticos, arquitectos, catedráticos y maestros de primera enseñanza.

El rastreo de los nombres de los integrantes de las mesas a través de la prensa permite advertir una cuestión más importante si cabe. Muchos de ellos contaban con un compromiso político en diferentes escenarios y contextos del espacio urbano madrileño antes de la Revolución. Esos precedentes resultan particularmente evidentes entre los presidentes de las mesas. La actividad politica de algunos de ellos se 
remontaba a la etapa revolucionaria de $1854^{42}$, sobresaliendo cuatro grupos específicos. Primero, los que ejercieron como jefes de las barricadas levantadas en las calles del sur de la ciudad entre los dias 17 y 19 de julio de aquel año, como el agente de negocios Nicolás Nieto, el sastre Manuel Laguna y el empleado Fernando Bada. Segundo, los que se distinguieron por conceder socorros a heridos y familias de los fallecidos en las luchas acaecidas en aquellas tres jornadas, como el comerciante José del Río, el empleado Nicolás Quintana, el pintor Juan Jalvo o el propietario Pedro Mediavilla. En tercer lugar, aquellos que se insertaron en las juntas de salvación o defensa y armamento tras los sucesos revolucionarios, como el propietario Isidoro Mata o el médico Pedro Díez. Y finalmente, los que destacaron en el alistamiento y la organización de la Milicia Nacional, reestablecida por el Ayuntamiento de Madrid para encuadrar a las fuerzas populares de las citadas barricadas ${ }^{43}$. Entre estos últimos se encontraban José Ruano y Elías Sáez, notarios y presidentes de las mesas de los barrios de Cava y Estudios en el distrito de la Audiencia en 1869; el farmacéutico Román Benito (barrio de Fuencarral) y el propietario Antonio Jacinto de Gassó, que asumió la vicepresidencia del batallón de la Milicia Nacional en el barrio de Caballero de Gracia y sus contornos ${ }^{44}$.

Un segundo sector de los integrantes de las presidencias de las mesas electorales de 1869 fijaba los origenes de su carrera política en el Bienio Progresista (1854-1856). Una etapa en la que algunos asumieron puestos de responsabilidad a nivel nacional, pero, sobre todo, en la ciudad de Madrid. El abogado Benigno Quirós, presidente de mesa en el barrio de Progreso del distrito de Audiencia, habia actuado como gobernador civil de la provincia de Guadalajara en ese ciclo político ${ }^{45}$, mientras que el contador José Carrión Anguiano, que ocupaba el mismo cargo que el anterior en el barrio de Atocha, habia sido compromisario electo del Senado ${ }^{46}$. Junto a ellos sobresalian quienes ya reflejaban una experiencia en el gobierno municipal de la capital española durante esa etapa. El tornero José Lancha (barrio de Plaza de Toros) y el tahonero Domingo Garrido (barrio de Caravaca) fueron ediles del Ayuntamiento de Madrid entre 1854 y 1856, institución en la que también participaba el ya mencionado Isidoro Mata, como síndico ${ }^{47}$.

En un tercer escenario se encontraban quienes iniciaron su militancia política entre 1856 y 1866, mayoritariamente en las filas de un Partido Progresista que entonces asistió a un ciclo de reorganización en Madrid acompañado por otro expansivo de movilización y configuración de espacios de

42 José Ramón de Urquijo, La revolución de 1854 en Madrid, Instituto de Historia Jerónimo Zurita, Madrid, 1984 y Pablo Sánchez León (ed.), Las jornadas de julio [de 1854] (Una crónica anónima de otro $15 \mathrm{M}$ en el pasado ciudadano español). Un Hijo del Pueblo, Postmetrópolis, Madrid, 2018.

43 Juan Sisinio Pérez Garzón, Milicia Nacional y Revolución Burguesa. El prototipo madrileño. 1808-1874, CSIC-Instituto Jerónimo Zurita, Madrid, 1978.

$44 \mathrm{La}$ reconstrucción de los datos de este párrafo se ha realizado a través de la consulta de: $L a$ España (2-8-1854 y 30-9-1854); El Clamor Público (29-7-1854, 8-8-1854, 22-8-1854 y 28-9-1854); La Nación, (3-8-1854; 4-8-1854; 12-8-1854; 30-8-1854, 8-9-1854, 23-9-1854 y 11-10-1854) y La Iberia, 26-7-1854.

\footnotetext{
45 La Nación, 18-8-1854

46 La Iberia y El Clamor Público, 12-12-1854 y 13-12-1854.

47 El Clamor Público, 28-7-1854 y La España, 26-12-1854.
} 
sociabilidad $^{48}$. Todos habían jugado un papel importante en las redes que dicha formación tejió a nivel de distrito, perteneciendo a las juntas directivas que aquella tenía establecidas en cada uno de ellos. Ofrecían, en segundo término, una experiencia en la preparación de los comicios municipales y legislativos que se celebraron en aquellos años al amparo del sufragio censitario, dada su condición de representantes de los comités electorales progresistas instaurados en las demarcaciones administrativas de la ciudad para esas citas. Y finalmente, buena parte de sus nombres podian hallarse en las listas de individuos que, combinando la actividad politica en el partido con la asistencial, habian organizado juntas a nivel de barrio para socorrer a los afectados por la epidemia de cólera de $1865^{49}$. Así ocurría en el distrito de Inclusa, uno de los más golpeados por la enfermedad. Los presidentes de las mesas de ocho de las diez secciones electorales correspondientes a sus barrios habian distribuido ayudas en metálico y especie en ese contexto ${ }^{50}$.

\section{Gráfico 5. Precedentes políticos de los presidentes de las mesas electorales de Madrid en 1869}

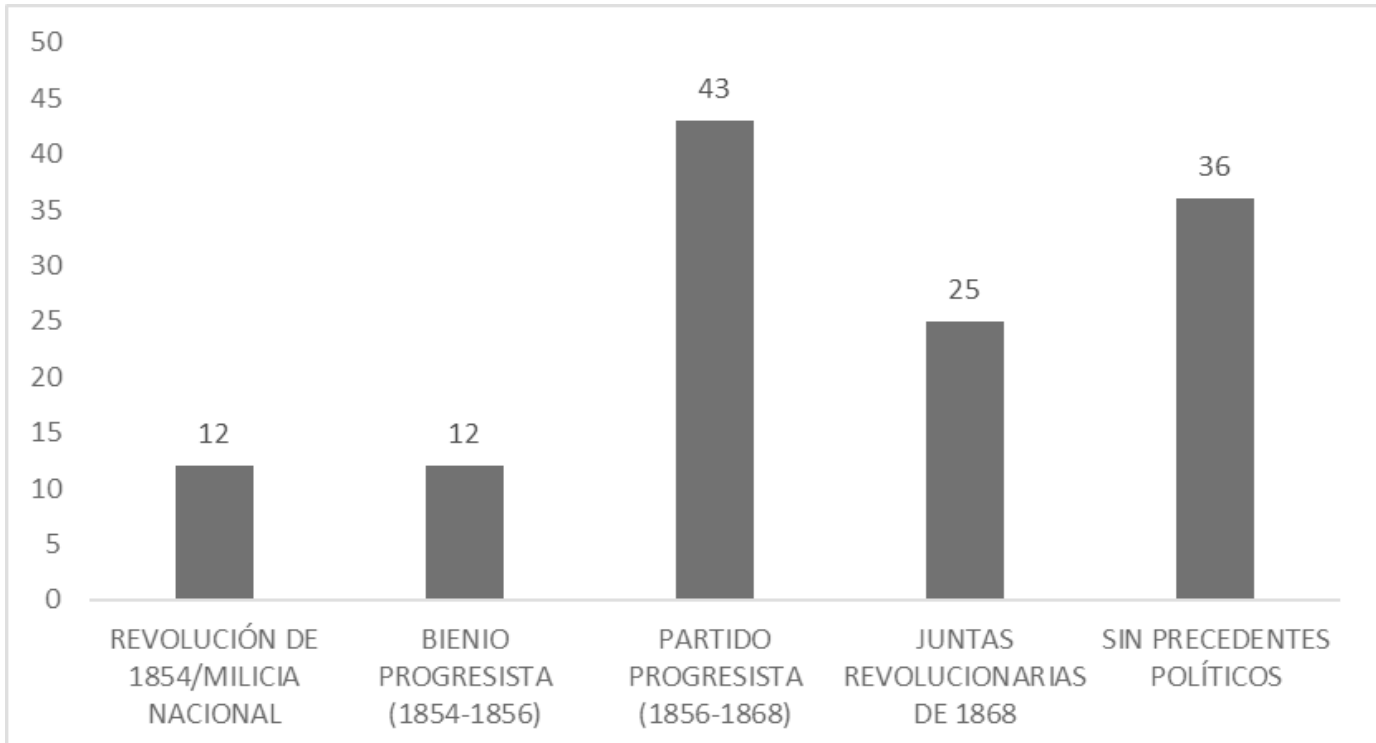

Fuente: Datos reconstruidos a partir de la información extraída de los siguientes diarios entre 1854 y 1868: La Nación, La España, El Clamor Público, La Discusión, La Soberanía Nacional, La Iberia, La Época y La Correspondencia de España.

48 Eduardo Higueras, "Las Tertulias Progresistas: un modelo de sociabilidad politica en el Sexenio Democrático (1868-1874)", Investigaciones Históricas. Época moderna y contemporánea, n 37 , 2017, pp. 8-39.

49 Nos referimos a la Asociación de Amigos de los Pobres, creada en octubre de 1865 e integrada por las bases sociales del progresismo. Su análisis en: Rubén Pallol, Una ciudad sin limites. Transformación urbana, cambio social y despertar politico en Madrid (1860-1875), Catarata, Madrid, 2013, pp. 74-86. En cuanto al impacto del cólera, véase: Antonio Fernández García, "Enfermedad y sociedad: el cólera de 1865 en Madrid”, Cuadernos de investigación histórica, n 3, 1979, pp. 155-186.

50 Los nombres a incluir son los de Domingo Garrido (tahonero, barrio de Caravaca); Luis López (sastre, barrio de Huerta del Bayo); Rafael Urosa (almacenista de maderas, barrio de Comadre); Marcos Lozano (comerciante, barrio del Rastro); Luis Pané (propietario, barrio de Peñuelas); Mariano Lesaca (comerciante, barrio del Peñón); Blas Lázaro (cesante, barrio de Embajadores) y Gabriel Madrid (comerciante, barrio de Cabestreros). Véase: La Soberanía Nacional, 13-10-1865. 
Finalmente, debe destacarse un último grupo formado por quienes aprovecharon la coyuntura revolucionaria de 1868 para involucrarse en los procesos políticos que se fueron dirimiendo tras ella en Madrid. Eran aquellos que figuraban ya en las juntas interinas que se constituyeron por aclamación a nivel de distrito en los dias 29 y 30 de septiembre de 1868, ya en las que se formaron mediante elección por sufragio universal en las primeras jornadas de octubre. Jugaron así un rol significativo en la transferencia pacífica del poder en la ciudad, preservando la tranquilidad y la seguridad a nivel de barrio, ya fuera transmitiendo advertencias a la población civil, ya fuera organizando cuerpos de guardia desplegados en patrullas de una tipología fundamentalmente política (Voluntarios de la Libertad) ${ }^{51}$. Su compromiso y su identificación con el nuevo orden revolucionario también se pudo advertir en los comicios municipales de diciembre de 1868. En esa coyuntura ya actuaron como presidentes y secretarios escrutadores de las mesas constituidas en los colegios de las secciones a nivel de barrio e incluso presentaron candidaturas para asumir alguna de las cuarenta y siete concejalías a elegir en Madrid. En este último escenario se encontraban algunos de los nombres ya mencionados. Isidoro Mata compitió por el distrito de Latina. Domingo Garrido y Rafael Urosa lo hicieron por el de Inclusa. Y el abogado Saturnino Celorio Rubín, por el distrito de Centro ${ }^{52}$.

En líneas generales, la intervención de las mesas no quedó en manos de individuos poco experimentados en la vida política de la etapa isabelina. Aun siendo cierto que muchos de ellos no contaban con derecho de voto reconocido por la legislación electoral durante aquel contexto, tenían una trayectoria ideológica y militante de notable arraigo, especialmente en lo que respecta al caso de los progresistas, que evidenciaban una participación consolidada en la organización de las citas electorales a las que la formación política había ido concurriendo en la capital desde 1860.

Tanto los presidentes como los secretarios escrutadores de las mesas electorales de Madrid asumieron competencias de una relevancia que no debe ser obviada en los comicios de 1869. Sus atribuciones resultaban decisivas en un contexto de incipiente politización. No se limitarian a leer en voz alta las cédulas de vecindad de cada elector y a comprobar su veracidad, como señalaba The Times. También cumplirian un papel de primera magnitud en la emisión del sufragio. Aplicando las apreciaciones de Villette para las elecciones legislativas de abril de 1848 en París ${ }^{53}$, actuarian como árbitros y mediadores del voto, papel que desempeñarian en un doble sentido.

Por un lado, tanto los presidentes como los secretarios escrutadores tomaban decisiones claves sobre la validez de las papeletas que los electores depositaban en las urnas, de acuerdo con las atribuciones que para ellos fijaba el decreto sobre el ejercicio del sufragio universal del 9 de noviembre de 1868. Las actas de los comicios legislativos vuelven a representar una fuente documental de gran importancia para analizar sus actuaciones, especialmente en lo que respecta a las protestas que presentaron los votantes y, sobre todo, las contramesas que

51 Juan Sisinio Pérez Garzón, Milicia Nacional y Revolución Burguesa, op. cit., pp. $508-516$ y Gregorio de la Fuente, Los revolucionarios de 1868, op. cit., pp. 67-118.

52 Autor, 2017.

53 Vincent Villette, Apprendre à voter, op. cit., pp. 209-216. 
pusieron en liza los comités electorales organizados por los republicanos a nivel de distrito.

Las situaciones más problemáticas a las que se enfrentaron las mesas tuvieron que ver con las características de las papeletas utilizadas por los votantes. Como se infiere a partir de las actas, una cifra muy elevada de aquellas presentaba membretes políticos ${ }^{54}$. Quienes formularon reclamaciones sobre la validez de estas papeletas las argumentaban en función de lo determinado en el artículo 54 del decreto sobre el ejercicio del sufragio universal, que dictaminaba que aquellas contendrian "solamente" los nombres de los candidatos a elegir en la circunscripción. Este fue el juicio que expresó el republicano Gregorio Pérez Altemir, al emitir su protesta en la mesa de la sección del barrio de Descalzas (distrito de Centro). El primer día de la elección solicitó la nulidad de las 139 papeletas que se iban a escrutar, al portar todas ellas calificaciones políticas. José Rafael Narváez, presidente de la mesa, debatió con los secretarios Andrés García, Simón Sánchez, Manuel Bermejo y Agustín Pinedo. Admitieron la reclamación y la incluyeron en acta, pero consideraron que no procedía su invalidez. A su juicio, "no se prejuzgaba nada con tales determinaciones, porque el que vota con ellas debe saber lo que significan". En las votaciones de los dias 17 y 18, Pérez Altemir repitió idéntico procedimiento en los otros nueve barrios del distrito y el mismo éxito ${ }^{55}$.

También fueron recurridos los votos provenientes de papeletas acompañadas en su parte superior por aclaraciones como "A votar para diputados a Cortes" o "Candidatura aprobada por los distritos y por la Junta Provincial Electoral de Madrid", considerándose que constituían un vicio legal evidente al ejercerse con ellas, sobre los votantes, una supuesta coacción "decisiva para lo que finalmente decidiera hacer cada elector con su derecho"56. De igual manera, se hicieron constar en acta los sufragios no presentados en papeletas de color blanco y los que citaban a los candidatos mencionando sus títulos nobiliarios en sustitución de sus nombres propios ${ }^{57}$. En estos dos últimos casos, el decreto del 9 de noviembre se mostraba más tajante en función de lo dispuesto en los artículos 34 y 9958. Pero en la práctica, y en líneas generales, las mesas mostraron permisividad con los mismos. Solo en la sección del barrio del Escorial, en el distrito de la Universidad y con una mesa integramente republicana, se

54 Entre ellos, "Candidatura Monárquico-Democrática para Diputados a Cortes", "Católicos, a las urnas. Catolicismo, Monarquía, economías hasta bajar el presupuesto de mil millones al año" o "Candidatura Republicana. Independencia, incorruptibilidad, fe". En: AVM-S, actas de las elecciones generales de 1869, 4-456-3 a 4-474-1.

55 AVM-S, actas de las elecciones generales de 1869, distrito de Centro, sig. 4-460.

56 AVM-S, actas de las elecciones generales de 1869, distrito de la Universidad, barrio de Pizarro, sigs. 4-458-1 y 4-459-1.

57 AVM-S, actas de las elecciones generales de 1869, distrito de Centro, barrio de Espejo, sig. 4-460.

58 El artículo 34 decretaba la obligatoriedad de las papeletas en blanco para el ejercicio del voto, mientras que el 99 consignaba la nulidad de las que no contuvieran nombres propios de los candidatos. En: Gaceta de Madrid, 10-11-1868. 
determinó la nulidad de las papeletas que presentaban las características señaladas ${ }^{59}$.

En lo que respecta al resto de protestas, no fueron numerosas si se comparan con las de posteriores elecciones del Sexenio en Madrid ${ }^{60}$, especialmente en lo referido a la votación de militares. Pese a ello, las mesas también mostraron una evidente tolerancia con respecto a aquellos casos que plantearon dudas. Estos últimos se refirieron a posibles delitos de coacción, en los que sargentos de regimientos acompañaban a soldados al ejercer el sufragio, como ocurrió en el barrio de Colón en el distrito de la Universidad, o en los que cabos de la Guardia Civil ingresaban en los colegios con los integrantes del cuerpo proveyéndoles en el mismo local de papeletas de la candidatura monárquico-democrática, como aconteció en el barrio de Cabestreros en el distrito de Inclusa61. Tampoco se anularon los votos, no obstante escasos a deducir por las actas, de militares desprovistos de las cédulas de filiación que debian entregarles sus jefes o los que se depositaron en las urnas de algunos colegios que no contaban con las listas de electores del Ejército y de la Armada ${ }^{62}$, las cuales debian ser remitidas ocho días antes de los comicios, como disponía el artículo 11 de la normativa electoral ${ }^{63}$. Estos ejemplos no deben llevar a pensar en prácticas de fraude, las cuales fueron muy limitadas como también demuestran los dos únicos casos encontrados sobre suplantación de identidad en el voto. Algo que explica por qué estos comicios se han entendido como los de mayor veracidad celebrados en el Sexenio ${ }^{64}$.

Sin embargo, los presidentes y los secretarios escrutadores de las mesas no sólo desempeñaron una función de arbitraje tolerante durante las jornadas de votación. Asimismo, cabría plantear la hipótesis de que ejercieron el papel de movilizadores en el ejercicio del sufragio. Más allá de las convicciones ideológicas que presentasen, no debe olvidarse un hecho fundamental: eran figuras de primer orden en el contexto socio-comunitario entendido a nivel de barrio. No sólo eran progresistas, unionistas, demócratas o republicanos. También eran profesionales liberales que habian acumulado un capital social en el enclave urbano en el que residian y que habian creado jerarquias o relaciones de ascendencia con respecto a su vecindario más próximo, ejerciendo como médicos, farmacéuticos, profesores y abogados y notarios. Eran fabricantes, industriales, almacenistas y comerciantes que, con una posición económica más o menos desahogada, jugaban un rol muy significativo en relaciones sociales de carácter

\footnotetext{
59 AVM-S, actas de las elecciones generales de 1869, distrito de la Universidad, barrio del Escorial, sigs. 4-458-1 y 4-459-1.

60 Carmen Pérez Roldán, Bases sociales del republicanismo madrileño (1868-1874), Tesis Doctoral, UCM, Madrid, 1998, pp. 323-401.

61 AVM-S, actas de las elecciones generales de 1869, distritos de la Universidad y de Inclusa, barrios de Colón y de Cabestreros, sigs. 4-458-1, 4-459-1 y 4-468-1.

62 AVM-S, actas de las elecciones generales de 1869, distrito de Inclusa, barrios de Peñón, Encomienda y Embajadores, sig. 4-468-1.

63 El voto militar en estas elecciones y la coacción en el mismo en: BAHAMONDE, Ángel, "Contribución al estudio del fraude electoral”, op. cit., pp. 644-651.

64 María Concepción Marcos del Olmo: "Las elecciones legislativas de 1869 en la provincia de Valladolid", op. cit., pp. 222-223.
} 
primario. Y eran, en último lugar, capataces, funcionarios y empleados de obras públicas que quizás podian llegar a ejercer un influjo moral donde habitaban.

La influencia que el anterior personal politico podía tener en unos comicios como los de 1869 pasa desapercibida si no se realiza un ejercicio metodológico concreto, basado en el análisis comparado de los libros-registros de electores y de las listas de votantes por barrios. El estudio de esa documentación evidencia unas discordancias significativas en la cadencia del voto entre unas calles y otras dentro de una misma sección electoral. En la mayoría de las ocasiones, dicha cadencia alcanzaba un tono ascendente coincidiendo con la presencia de uno o varios integrantes de una mesa en una zona específica del vecindario. Uno de los casos más ejemplificadores puede encontrarse en el barrio de Embajadores, en el distrito de Inclusa. Determinados tramos de la vía pública que daba nombre a aquella demarcación mostraban una fuerte movilización que podría asociarse al papel jugado por el mencionado personal político. Así puede apreciarse en los edificios comprendidos entre los números 46 y 62 de esa calle, donde confluían el presidente de la mesa de la sección electoral (Blas Lázaro), la figura que compitió con el anterior por ese cargo (Ramón Algarra) y uno de los cuatro secretarios escrutadores (Timoteo Sáenz de Tejada). Los tres eran comerciantes. Algo similar se advierte en los inmuebles situados en los números impares de la misma vía (31 a 57), en la que convivian los otros tres secretarios escrutadores (el empleado Antonio Pérez, el sastre Manuel López y el barbero Marcelino Montero) ${ }^{65}$.

La correlación entre movilización y presencia de cargos de las mesas también era clara en la Costanilla de Santiago, una de las calles que comprendía el barrio de Espejo, en el distrito de Centro. En sus números pares, era el abogado Saturnino Celorio Rubín quien buscaba movilizar a sus vecinos repartiendo candidaturas monárquico-democráticas con su nombre para la presidencia de la mesa. En los impares hacía lo propio el tabernero Fernando Con, recién iniciado en las filas del republicanismo federal. Su influencia parecía evidente. En el número 6 de la calle, donde habitaba Celorio Rubín, votaron todos los inquilinos empadronados con derecho de sufragio reconocido tanto en la jornada en que se dirimía la mesa como en las que se elegían los candidatos. Lo mismo ocurrió en el edificio de vecindad situado en el número 3 de la calle, donde vivía Con, si bien en este último caso la movilización se extendió a las fincas colindantes ${ }^{66}$.

Un comportamiento electoral similar al de Embajadores y Espejo puede advertirse en otros barrios de Madrid. Quizás en ellos, la población no siempre acudía a los colegios por el compromiso que tenía con unos principios ideológicos que, en cierto modo, podian resultar abstractos en 1869. Parece plausible la idea de que también lo hacian por los lazos construidos con los candidatos a las mesas, de acuerdo con el papel socio-económico que estos asumían en su comunidad. Precisamente sería este el vector que podría haber llevado a algunos de los que en enero de 1869 actuaron como presidentes y secretarios escrutadores a iniciar carreras politicas de mayor alcance en la escena local, postulándose en posteriores citas electorales como candidatos a las concejalías. Un camino que iniciaron algunos de los nombres ya aquí citados, como el

65 AVM-S, libros-registros de electores y listas de votantes de las elecciones generales de 1869 , distrito de Inclusa, barrio de Embajadores, sigs. 4-468 y 4-469.

66 AVM-S, libros-registros de electores y listas de votantes en las elecciones de 1869 en el distrito de Centro (barrio de Espejo), sigs. 4-460 y 4-499-3. 
tahonero Domingo Garrido, el almacenista de maderas Rafael Urosa o el abogado Saturnino Celorio Rubín, y que continuarian, entre otros, Fernando Con, para convertirse en el edil más votado del distrito de Centro en la Primera República67.

\section{EL VOTO EN SU CONTEXTO}

Poco resta por añadir sobre las tendencias políticas del voto en las elecciones generales de 1869 en Madrid. Los estudios que han abordado esos comicios han hecho interpretaciones depuradas de las candidaturas presentadas, de las campañas electorales y de los resultados en las urnas ${ }^{68}$. Asimismo, esos trabajos se han servido de variables para interpretar el escrutinio en conexión con la composición social de la ciudad. En este sentido, la proporción de contribuyentes, de nobles o la cuantía de los alquileres por distritos o barrios, permitirian advertir, a la altura de 1869, rasgos definitorios que la sociología electoral clásica vislumbró en sucesivas citas politicas durante la Restauración ${ }^{69}$, esto es, brechas en las tendencias políticas del voto en función de las características socioeconómicas del núcleo urbano ${ }^{70}$. En el caso de las elecciones aquí abordadas, los distritos de Hospital, Inclusa, Universidad y Latina habrian favorecido, en mayor o menor medida, el voto republicano por ser los más proclives a recabarlo, consecuencia de una mayor concentración de clases populares. Todo lo contrario habría ocurrido en Centro, Audiencia, Buenavista, Congreso, Hospicio y Palacio, que cobijaban a sectores más acomodados.

Aunque el conocimiento sobre estas elecciones es rico, quedan por responder preguntas de relevancia que permitan sacar conclusiones sobre los vínculos reales que pudieron existir entre el acto del voto y el contexto social y cultural en el que se ejercia ${ }^{71}$. Entre ellas, podriamos destacar tres: ¿Qué grupos socioprofesionales mostraron un mayor grado de movilización en la cita electoral y qué elementos pudieron influir en la misma? ¿Qué papel desempeñó la variable comunitaria en el escrutinio de ciertos barrios o en la concurrencia en los colegios donde se votaba? ¿Realmente fue la composición social del vecindario el elemento que pudo guiar la tendencia politica del voto en ciertas zonas?

La respuesta a estas preguntas pasa por la ampliación de la escala de observación y la descripción densa en el estudio de los procesos electorales ${ }^{72}$, que

67 Fernando Con salió electo en los comicios locales de 1873 con un 83,52\% de los votos emitidos. En: AVM-S, actas de las elecciones municipales de 1873, sig. 5-43-3.

68 Ángel Bahamonde, "Contribución al estudio del fraude electoral en un distrito urbano. Las elecciones de 1869 en Madrid", op. cit. y Antonio Fernández García, "El estreno del sufragio universal en Madrid (1869)", op. cit.

69 Javier Tusell, Sociología electoral de Madrid, 1903-1931, Edicusa, Madrid, 1969.

70 Antonio Moreno y Ángel Bahamonde, "Sociedad y comportamiento electoral: geografía del voto en el Madrid de 1869", Revista de la Universidad Complutense, vol. 116, 1979, pp. 147-182.

71 Raffaele Romanelli (ed.), How they did become voters? The History of Franchise in Modern European Representation, Kluwer Law, Massachussets, 1998; Hilda Sábato, "On political citizenship in Nineteenth-Century Latin America", The American Historical Review, vol. 106, $\mathrm{n}^{\circ} 4$, 2001, pp. 1290-1315; Antonio Annino, "El voto y el desconocido siglo XIX", op. cit.; Michel Offerlé: "De l'histoire électorale à la socio-histoire des électeurs", op. cit. y Fausta Gantús y Alicia Salmerón, "Un acercamiento a las elecciones del México del siglo XIX", op. cit.

72 De cara a ilustrar el carácter significativo que presenta la ampliación de la escala de observación en el estudio de los resultados electorales de espacios urbanos concretos, véanse los 
para el caso concreto de este trabajo se aplica desde el aprovechamiento de los datos que aporta la documentación tramitada por el Ayuntamiento de Madrid para los comicios generales. Los libros-registros de electores, que indican su actividad profesional y su espacio residencial, y las listas de votantes, que muestran la presencia o ausencia de aquellos en las jornadas de votación, vuelven a ser fuentes claves para ese ejercicio ${ }^{73}$, sin olvidar los recursos que aporta la prensa, al ayudar a discernir el tejido político y social existente en determinadas zonas de Madrid antes de la implantación del sufragio universal.

\section{Gráfico 6. Muestra de barrios analizados en las elecciones generales de 1869 en Madrid}

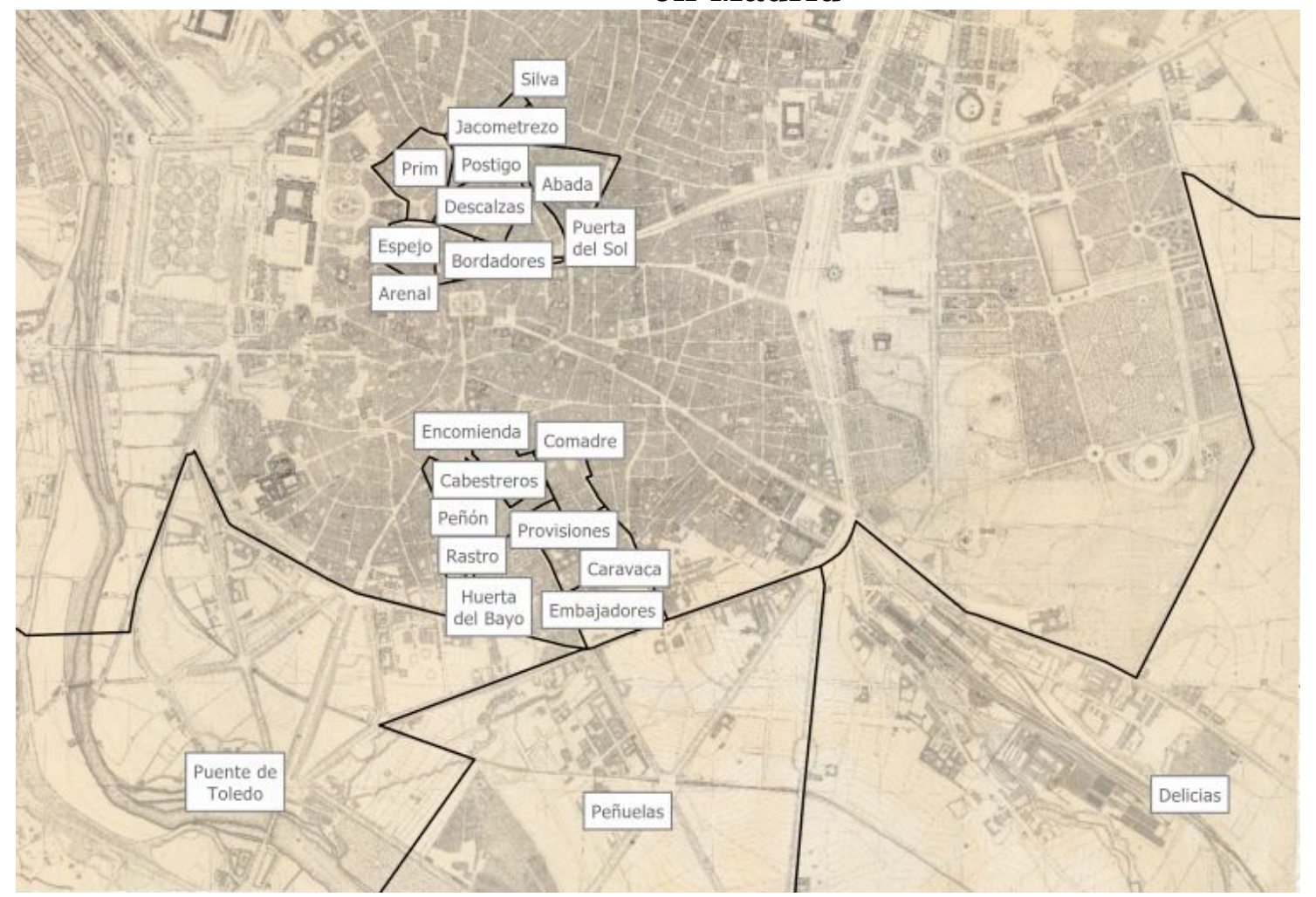

Elaboración propia sobre el Plano de Madrid formado por el Instituto Geográfico y Estadístico bajo la dirección de Carlos Ibáñez e Ibáñez de Íbero (1872-1874).

Para el estudio de las anteriores cuestiones, se han seleccionado veintidós de los cien barrios comprendidos en Madrid, en función de los criterios que guían su análisis. Diez de ellos se corresponden con el distrito de Centro (Abada, Arenal, Bordadores, Descalzas, Espejo, Jacometrezo, Postigo, Prim, Puerta del Sol y Silva), que contaba con la cifra de electores más elevada de la ciudad antes de la aprobación del sufragio universal masculino, merced a la fuerte representatividad que en él tenían contribuyentes y capacidades. Otros diez se asociarian al distrito de Inclusa (Cabestreros, Caravaca, Comadre, Embajadores, Encomienda, Huerta del Bayo, Peñón, Peñuelas, Provisiones y Rastro), que

trabajos de Brodie para el East End en: Marc Brodie, The politics of the poor. The East End of London, 1885-1914, Clarendon Press, Oxford, 2004.

${ }^{73}$ La utilidad metodológica de esta documentación en: Fausta Gantús (coord.), Elecciones en el México del siglo XIX. Las fuentes, Instituto Mora, México, 2015. Resultados de la importancia de su aplicación para rebatir interpretaciones sobre el voto ligado al contexto urbano en: Marc Brodie, The politics of the poor, op. cit. 
agrupaba buena parte de los barrios del sur del casco antiguo y que se definía por unas características socioeconómicas opuestas a las del anterior. Los otros dos barrios se corresponden con espacios periféricos que, o bien eran virginales en términos electorales y de politización durante la etapa isabelina (Puente de Toledo en el suroeste), o bien acababan de anexionarse a Madrid con la aprobación del proyecto de Ensanche de Carlos María de Castro ${ }^{74}$ (Delicias en el Ensanche Sur).

El distrito de Centro resultó una de las zonas menos proclives para los intereses del republicanismo en las elecciones de 1869. Dentro de la candidatura monárquico-democrática, Nicolás Maria Rivero fue el más votado, apareciendo en casi un $70 \%$ de las papeletas depositadas en las urnas. En la republicana, Estanislao Figueras sólo pudo lograr un 22,32\% de los sufragios emitidos en el cómputo de los diez barrios de esta demarcación. Sin olvidar la importancia de estos resultados, interesa analizar aquí las características que revistieron a los patrones de movilización de los habitantes de este espacio urbano, ligados con su clasificación profesional. El censo electoral del distrito refleja la heterogeneidad social arquetípica de un modelo residencial que, como consecuencia del predominio de una segregación vertical, daba cabida a todo tipo de sectores laborales $^{75}$. Desde los trabajadores del sector de la producción, que asumian el protagonismo en términos globales, a los profesionales liberales, pasando por los trabajadores de ventas, los trabajadores de servicios personales y los oficinistas y funcionarios.

Todos los grupos profesionales señalados mostraron unos altos índices de movilización en los comicios. Los más reducidos se correspondieron con los trabajadores de servicios personales. Entre estos últimos sobresalían a los que se dedicaban al servicio doméstico interno. Su situación laboral de dependencia no parecía venir acompañada por una concurrencia particularmente elevada en los colegios electorales. Pese a ello, no faltan casos en los que se aprecian prácticas de voto que podrian correlacionarse con una obediencia debida con respecto a la figura que actuaba como $\mathrm{amo}^{76}$. El posible condicionamiento del ejercicio del sufragio dentro del anterior escenario podia verificarse con mayor claridad en el grupo social conformado por los grandes propietarios. Algo así se deduciría de lo acaecido en dos edificios colindantes situados en los números 6 y 8 de la calle Mayor, en el barrio de Bordadores. Ambos pertenecían al conde de Oñate. La totalidad de su servicio doméstico, integrado por veinticinco empleados, acudió al colegio electoral a emitir su voto. Un ejemplo que no resultaba aislado y que tenía su correlato en otras casas como la del duque de Frías en la calle de Fomento o la del capitalista Antonio Gaviria, en la calle de los Caños, las dos en el barrio de Prim ${ }^{77}$. Dentro del conjunto de oficinistas y funcionarios, eran los empleados públicos los que ofrecian una movilización más elevada, si bien resulta complicado discernir el influjo moral que pudo ejercerse sobre los vinculados al

74 Borja Carballo, Rubén Pallol y Fernando Vicente, El Ensanche de Madrid. Historia de una capital, Editorial Complutense, Madrid, 2008.

75 Autor, 2016.

76 Gregorio de la Fuente, "Élite politica y clientelismo durante el Sexenio Democrático", op. cit., pág. 149.

77 AVM-S, actas de las elecciones generales de 1869, distrito de Centro, barrios de Bordadores y Prim, sigs. 4-460-1, 4-461-1 y 4-499-3. 
Estado o, sobre todo, al Ayuntamiento, coacción que se denunció de manera sistemática por la prensa republicana ${ }^{78}$. Y finalmente, cabe destacar el voto emitido por los trabajadores del sector de la producción, grupo en el que se abrian diferencias sensibles entre la movilización mostrada por los que evidenciaban una especialización reconocida en su oficio (industrias de las artes gráficas, procesado de comidas y bebidas, construcción, el vestido y confección, joyería y metales preciosos) y los no cualificados (braceros y jornaleros).

\section{Tabla 4. Electores de los barrios del distrito de Centro por categoria profesional 79}

\begin{tabular}{|c|c|c|c|c|c|}
\hline Barrio & $\begin{array}{c}\text { Profesionales } \\
\text { liberales y } \\
\text { técnicos } \\
\text { (HISCO 0/ 1) }\end{array}$ & $\begin{array}{c}\text { Oficinistas } \\
\text { y } \\
\text { funcionarios } \\
\text { (HISCO 3) }\end{array}$ & $\begin{array}{c}\text { Trabajadores } \\
\text { de ventas } \\
\text { (HISco 4) }\end{array}$ & $\begin{array}{c}\text { Trabajadores } \\
\text { de servicios } \\
\text { personales } \\
\text { (HISCO 5) }\end{array}$ & $\begin{array}{c}\text { Trabajadores } \\
\text { del sector de } \\
\text { la producción } \\
\text { (HISCO 7/8/9) }\end{array}$ \\
\hline Abada & $11,92 \%$ & $15,38 \%$ & $19,91 \%$ & $16,29 \%$ & $34,24 \%$ \\
\hline Arenal & $13,05 \%$ & $14,97 \%$ & $19 \%$ & $18,23 \%$ & $33,01 \%$ \\
\hline Bordadores & $11,09 \%$ & $13,06 \%$ & $23,26 \%$ & $21,11 \%$ & $30,95 \%$ \\
\hline Descalzas & $12,26 \%$ & $13,98 \%$ & $12,04 \%$ & $27,96 \%$ & $30,32 \%$ \\
\hline Espejo & $10,21 \%$ & $16,44 \%$ & $8,65 \%$ & $25,26 \%$ & $38,93 \%$ \\
\hline Jacometrezo & $12,55 \%$ & $16,48 \%$ & $14,04 \%$ & $20,60 \%$ & $34,64 \%$ \\
\hline Postigo & $13,01 \%$ & $16,76 \%$ & $10,12 \%$ & $15,61 \%$ & $43,64 \%$ \\
\hline Prim & $14,26 \%$ & $15,16 \%$ & $13 \%$ & $24,19 \%$ & $30,51 \%$ \\
\hline $\begin{array}{c}\text { Puerta del } \\
\text { Sol }\end{array}$ & $11,59 \%$ & $10,09 \%$ & $30,09 \%$ & $21,50 \%$ & $25,79 \%$ \\
\hline Silva & $16,56 \%$ & $14,88 \%$ & $10,43 \%$ & $19,48 \%$ & $37,73 \%$ \\
\hline $\begin{array}{c}\text { Media } \\
\text { distrito }\end{array}$ & $\mathbf{1 2 , 6 9 \%}$ & $\mathbf{1 4 , 6 8 \%}$ & $\mathbf{1 6 , 2 4 \%}$ & $\mathbf{2 1 , 0 3 \%}$ & $\mathbf{3 3 , 7 9 \%}$ \\
\hline
\end{tabular}

Fuente: AVM-S, libros-registros de electores y listas de votantes de las elecciones generales de 1869, barrios del distrito de Centro, sigs. 4-460-1, 4-461-1 y 4-499-3.

Pero si habría que centrarse en un grupo laboral en concreto por su movilización, sería en el constituido por los trabajadores de ventas. Prácticamente ocho de cada diez integrantes de ese sector acudieron a las urnas en el distrito. En los barrios de mayor tradición mercantil, esa proporción se elevaba de manera sustancial. Eran los casos de Puerta del Sol, Arenal o Bordadores, que concentraban los establecimientos de mayor renombre y prestigio de la zona en algunas de sus principales vías públicas. Únicamente en algunos de los espacios en los que la presencia de comerciantes era más reducida, se rebajaba su afluencia en las urnas, como se evidencia en los barrios de Descalzas o Postigo.

\footnotetext{
${ }^{78}$ Ángel Bahamonde, “Contribución al estudio del fraude electoral”, op. cit.

79 Tanto en esta tabla como en las venideras sobre especialización profesional correlacionada con voto se utilizan las categorías definidas en la clasificación internacional de ocupaciones profesionales HISCO. En: Marco Van Leeuwen, Ineke Maas y Andrew Miles, HISCO. Historical International Standard Classification of Occupations, Leuven, Leuven University Press, 2002. Su traducción al castellano en el proyecto HISPA-HISCO, visible en: https://hicodigos.wordpress.com
} 
Tabla 5. Movilización del voto por categoria profesional en los barrios del distrito de Centro

\begin{tabular}{|c|c|c|c|c|c|c|}
\hline Barrio & HISCO & HISCO & HISCO & HISCO & HISCO & Jornaleros $^{\mathbf{8 0}}$ \\
\hline Abada & $73,42 \%$ & $78,43 \%$ & $78,79 \%$ & $72,22 \%$ & $75,77 \%$ & $65,79 \%$ \\
\hline Arenal & $70,59 \%$ & $76,92 \%$ & $83,84 \%$ & $63,16 \%$ & $67,44 \%$ & $60 \%$ \\
\hline Bordadores & $77,42 \%$ & $72,60 \%$ & $83,85 \%$ & $71,19 \%$ & $76,30 \%$ & $77,78 \%$ \\
\hline Descalzas & $61,40 \%$ & $69,23 \%$ & $57,14 \%$ & $63,85 \%$ & $69,50 \%$ & $52 \%$ \\
\hline Espejo & $61,02 \%$ & $68,42 \%$ & $72 \%$ & $62,33 \%$ & $66,67 \%$ & $68,33 \%$ \\
\hline Jacometrezo & $56,72 \%$ & $65,91 \%$ & $77,33 \%$ & $57,27 \%$ & $68,11 \%$ & $55,17 \%$ \\
\hline Postigo & $64,44 \%$ & $70,69 \%$ & $65,71 \%$ & $74,07 \%$ & $69,54 \%$ & $68,42 \%$ \\
\hline Prim & $64,56 \%$ & $72,62 \%$ & $79,17 \%$ & $62,69 \%$ & $72,78 \%$ & $59,38 \%$ \\
\hline $\begin{array}{c}\text { Puerta del } \\
\text { Sol }\end{array}$ & $72,58 \%$ & $74,07 \%$ & $81,99 \%$ & $70,43 \%$ & $78,99 \%$ & $53,85 \%$ \\
\hline Silva & $68,52 \%$ & $74,23 \%$ & $82,35 \%$ & $75,59 \%$ & $77,24 \%$ & $67,50 \%$ \\
\hline $\begin{array}{c}\text { Media } \\
\text { distrito }\end{array}$ & $\mathbf{6 7 , 3 5 \%}$ & $\mathbf{7 2 , 4 2} \%$ & $\mathbf{7 8 , 5 9} \%$ & $\mathbf{6 6 , 8 4} \%$ & $\mathbf{7 2 , 3 0} \%$ & $\mathbf{6 4 , 0 9} \%$ \\
\hline
\end{tabular}

Fuente: AVM-S, libros-registros de electores y listas de votantes de las elecciones generales de 1869, distrito de Centro, sigs. 4-460-1, 4-461-1 y 4-499-3.

Con anterioridad a la Revolución de 1868, los barrios del distrito de Centro no sólo se habían caracterizado por contener las representaciones más elevadas de electores y elegibles. De igual manera, eran enclaves en los que los partidos habian tejido unas notorias redes organizativas, especialmente en lo que respecta al caso de los progresistas. En la junta directiva del Partido Progresista en esa zona eran los comerciantes los que llevaban el mayor peso proporcional con respecto a otros sectores profesionales. Entre ellos descollaban figuras como Simón Pérez y Melitón Arana. El primero era propietario de un almacén de precios fijos en el número 1 de la calle Mayor y el segundo regentaba un bazar de ropas hechas en el número 13 de idéntica vía pública. Ya en 1860 se habian postulado como candidatos a las concejalias del distrito. Una vez obtenidas, habian tomado decisiones relevantes para la elaboración de las listas de primera rectificación en las elecciones municipales de 1862 y 186481. Asimismo, los correligionarios de su partido debian dirigirse a sus establecimientos para conseguir los documentos que acreditasen su derecho al voto cuando se aproximaban los mencionados comicios. Y finalmente, tenían una causa en común: la labor asistencial desarrollada en la ya mencionada Asociación de Amigos de los Pobres ${ }^{82}$.

Tanto Simón Pérez como Melitón Arana participaron en la junta revolucionaria interina del distrito de Centro formada el 29 de septiembre de 1868. El primero se convirtió en jefe del batallón de los Voluntarios de la Libertad a principios de octubre, mientras que el segundo lideró a la fuerza ciudadana instalada en el barrio para mantener el orden público. En las elecciones de 1869, su liderazgo y su capacidad movilizadora del voto en el barrio al que pertenecian, el de Bordadores, fue incuestionable. Pérez llegó incluso a actuar como una figura decisiva a la hora de hacer llegar las cédulas electorales a los vecinos de la zona,

80 Forman parte del grupo HISCO 7/8/9 (Trabajadores del sector de la producción).

81 AVM-S, actas de las elecciones municipales de 1860, 1862 y 1864, distrito de Centro, sigs. 4-188-10, 4-338-37 y 4-258-13.

82 La Iberia, 11-8-1865 y 12-8-1865. 
como refleja su participación en ese proceso ayudando al alcalde de barrio Antonio Monedero, otro destacado comerciante de la zona con el que compartía militancia ${ }^{83}$.

Al margen del voto que pudieran recabar para la candidatura monárquicodemocrática los presidentes y los secretarios escrutadores de las mesas, no debe pasarse por alto la influencia que podian tener figuras como Simón Pérez y Melitón Arana a nivel comunitario. Desde luego, así parecía ocurrir entre los de su condición profesional, teniendo en cuenta que nueve de cada diez comerciantes emitieron el sufragio durante la cita electoral en el barrio de Bordadores al que ambos pertenecian. Y a buen seguro que habian jugado un papel importante en la movilización de sus vecinos. En la citada finca número 1 de la calle Mayor en la que vivía Simón Pérez votaron los treinta habitantes que tenían reconocido el derecho político ${ }^{84}$.

El papel de Simón Pérez y Melitón Arana en Bordadores podría rescatarse en otras muchas zonas del distrito, visible en figuras que también habian tomado un partido decidido en el progresismo. Nombres como el de Isidro Rodríguez, que a su actividad politica sumaba el haber encabezado la recaudación de donativos en el barrio de la Abada durante la lucha contra el cólera en 1865 y el haber dirigido uno de los batallones de los Voluntarios de la Libertad en el distrito. O como el de Francisco Delgado, cuya impronta social parecía advertirse en la enorme movilización electoral que vivieron los números pares de la calle de Tudescos en la que habitaba, al congregarse en las urnas la mayoría de los alli residentes. Su relevancia en los citados barrios ya se había podido observar en las elecciones municipales de 1868. En ellas, resultaron abrumadoramente apoyados por sus vecinos, incluso sin formar parte de la candidatura monárquico-democrática ${ }^{85}$.

Tabla 6. Movilización del voto por especialización profesional en el distrito de Centro

\begin{tabular}{|c|c|c|c|c|}
\hline Especialización profesional & Votan & $\begin{array}{c}\text { No votan } \\
0 \\
\text { carecen } \\
\text { de } \\
\text { cédulas }\end{array}$ & Total & $\begin{array}{c}\text { Votan } \\
(\%)\end{array}$ \\
\hline Propietarios y dependientes de comercio & 545 & 140 & 685 & $79,56 \%$ \\
\hline Empleados, oficinistas y similares & 503 & 175 & 678 & $74,19 \%$ \\
\hline Trabajadores del servicio doméstico & 198 & 129 & 327 & $60,55 \%$ \\
\hline Jornaleros & 191 & 107 & 298 & $64,09 \%$ \\
\hline Juristas (abogados, notarios y jueces) & 143 & 81 & 224 & $63,84 \%$ \\
\hline Sastres, modistos y similares & 165 & 48 & 213 & $77,46 \%$ \\
\hline Porteros y guardas de edificios & 148 & 43 & 191 & $77,49 \%$ \\
\hline $\begin{array}{c}\text { Trabajadores en procesado de comidas y } \\
\text { bebidas }\end{array}$ & 134 & 59 & 193 & $69,43 \%$ \\
\hline
\end{tabular}

83 AVM-S, LAAM, sesión ordinaria del 6 de enero de 1869.

84 AVM-S, actas de las elecciones generales de 1869, distrito de Centro, barrio de Bordadores, sigs. 4-460 y 4-499-3.

85 Francisco Delgado obtuvo un 65\% de los votos del barrio al que pertenecía, Silva, mientras que Isidro Rodríguez cosechó un $60 \%$ en Abada. En: AVM-S, actas de las elecciones municipales de 1868, distrito de Centro, sigs. 4-446-1 y 4-447-1. 


\begin{tabular}{|c|c|c|c|c|}
\hline $\begin{array}{c}\text { Zapateros y trabajadores de la confección de } \\
\text { cueros }\end{array}$ & 117 & 35 & 152 & $76,97 \%$ \\
\hline Impresores y similares & 102 & 29 & 131 & $77,86 \%$ \\
\hline Ebanistas, carpinteros y similares & 92 & 33 & 125 & $73,60 \%$ \\
\hline Camareros & 79 & 41 & 120 & $65,83 \%$ \\
\hline Aguadores & 58 & 49 & 107 & $54,21 \%$ \\
\hline Conductores de vehículos de tracción animal & 59 & 36 & 95 & $62,11 \%$ \\
\hline Taberneros & 61 & 22 & 83 & $73,49 \%$ \\
\hline Albañiles & 55 & 27 & 82 & $67,07 \%$ \\
\hline Médicos & 52 & 27 & 79 & $65,82 \%$ \\
\hline Mozos de cuerda & 59 & 19 & 78 & $75,64 \%$ \\
\hline Profesores y maestros de enseñanza & 48 & 12 & 60 & $80 \%$ \\
\hline Religiosos & 26 & 33 & 59 & $44,07 \%$ \\
\hline Pintores de obras y edificios & 35 & 18 & 53 & $66,04 \%$ \\
\hline Carboneros & 33 & 16 & 49 & $67,35 \%$ \\
\hline Peluqueros y barberos & 38 & 10 & 48 & $79,17 \%$ \\
\hline Joyeros y trabajadores de metales pre & 36 & 5 & 41 & $87,80 \%$ \\
\hline
\end{tabular}

Fuente: AVM-S, actas, libros-registros de electores y listas de votantes de las elecciones generales de 1869, distrito de Centro, sigs. 4-460-1, 4-461-1 y 4-499-3.

Sin embargo, la importancia de los comerciantes iba más allá de las ideas politicas que profesaran. Como ya han señalado Crossick o Haupt para el ámbito europeo, sus establecimientos eran claves a la hora de proporcionar estructura, continuidad y memoria a los barrios en los que residian, siendo, por lo general, quienes mostraban los mayores niveles de estabilidad residencial a través del funcionamiento de sus negocios ${ }^{86}$. Negocios que, por otro lado, no sólo representaban espacios de sociabilidad y reunión popular, sino también marcos de abastecimiento de una atmósfera social integradora y enclaves desde los que se ofrecía asistencia con carácter ocasional. Todo ello nos habla de una fuerza económica y social que, en el contexto de un barrio, que en definitiva constituía un pequeño mundo de relaciones cotidianas primarias a la altura de 1869, podia tener su correlato en una tercera fuerza politica, desplegada en términos de movilización del voto.

Buena parte de los anteriores apuntes servirian para los trabajadores de ventas del distrito de Inclusa, si bien a una escala más reducida. Aquí fue donde el republicanismo obtuvo sus mayores apoyos, favorecido por un $41,43 \%$ del electorado. Resulta cierto que la condición socioeconómica de sus barrios podría consignarse como un factor que podia garantizar un mayor voto republicano. La mayoria de sus inmuebles se ajustaban al modelo del edificio de vecindad que combinaba escasa línea de fachada y gran desarrollo de fondo. Un hecho que daba lugar a que las diferencias entre las habitaciones de una misma finca fuesen menos pronunciadas que las de otras zonas de la ciudad. Así, frente a la separación estamental en altura de los barrios del centro en el interior de una misma finca, un número importante de los del sur del casco antiguo, como los de Inclusa, planteaban la disociación social entre viviendas interiores y exteriores.

Quizás la mayor uniformidad social del distrito de Inclusa evitaba que se dibujasen contrastes abruptos en el signo del voto. No en vano, fue la única zona de la ciudad en la que se dio una verdadera competitividad entre la candidatura

86 Geoffrey Crossick y Heinz-Gerhard Haupt, The petite bourgeoisie in Europe, 1780-1914, Routledge, London, 1995. 
monárquico-democrática y la republicana. Esa competitividad se desequilibró en favor de la primera gracias a la superioridad de su voto en la primera y la tercera jornada de la elección. En prácticamente todos los barrios del distrito se cumplió el pronóstico que los republicanos habian hecho en la prensa en los días previos a los comicios, al vaticinar una movilización más intensa de la población coincidiendo con el domingo 17 de enero, día en el que, a su juicio, podían acudir a las urnas los trabajadores asalariados que mejor podian representar a sus bases sociales ${ }^{87}$.

\section{Tabla 7. Electores de los barrios del distrito de Inclusa por categoria profesional}

\begin{tabular}{|c|c|c|c|c|c|}
\hline Barrios & $\begin{array}{c}\text { Profesionales } \\
\text { liberales y } \\
\text { técnicos } \\
\text { (HISco 0/ 1) }\end{array}$ & $\begin{array}{c}\text { Oficinistas } \\
\text { funcionarios } \\
\text { (HISCO 3) }\end{array}$ & $\begin{array}{c}\text { Trabajadores } \\
\text { de ventas } \\
\text { (HISCO 4) }\end{array}$ & $\begin{array}{c}\text { Trabajadores } \\
\text { de servicios } \\
\text { personales } \\
\text { (HISCO 5) }\end{array}$ & $\begin{array}{c}\text { Trabajadores } \\
\text { del sector } \\
\text { de la } \\
\text { produccion } \\
\text { (HISCO } \\
\mathbf{7 / 8 / 9 )}\end{array}$ \\
\hline Cabestreros & $4,33 \%$ & $6,32 \%$ & $8,08 \%$ & $8,20 \%$ & $72,13 \%$ \\
\hline Caravaca & $0,52 \%$ & $4,24 \%$ & $3,72 \%$ & $5,79 \%$ & $84,92 \%$ \\
\hline Comadre & $3,86 \%$ & $8,43 \%$ & $8,55 \%$ & $10,60 \%$ & $67,71 \%$ \\
\hline Embajadores & $1,16 \%$ & $3,28 \%$ & $6,17 \%$ & $6,74 \%$ & $81,31 \%$ \\
\hline Encomienda & $6,66 \%$ & $11,65 \%$ & $11,95 \%$ & $9,83 \%$ & $57,79 \%$ \\
\hline $\begin{array}{c}\text { Huerta del } \\
\text { Bayo }\end{array}$ & $0,71 \%$ & $3,00 \%$ & $5,21 \%$ & $6,00 \%$ & $83,58 \%$ \\
\hline Peñón & $1,47 \%$ & $5,51 \%$ & $9,18 \%$ & $14,20 \%$ & $67,56 \%$ \\
\hline Peñuelas & $1,36 \%$ & $3,40 \%$ & $2,98 \%$ & $6,04 \%$ & $84,18 \%$ \\
\hline Provisiones & $3,02 \%$ & $2,62 \%$ & $3,67 \%$ & $9,45 \%$ & $80,71 \%$ \\
\hline Rastro & $1,51 \%$ & $2,52 \%$ & $16,52 \%$ & $10,34 \%$ & $67,34 \%$ \\
\hline $\begin{array}{c}\text { Media } \\
\text { distrito }\end{array}$ & $\mathbf{2 , 2 9 \%}$ & $\mathbf{4 , 9 1 \%}$ & $\mathbf{7 , 2 2} \%$ & $\mathbf{8 , 4 9 \%}$ & $\mathbf{7 5 , 6 7 \%}$ \\
\hline
\end{tabular}

Fuente: AVM-S, actas, libros-registros de electores y listas de votantes de las elecciones generales de 1869, barrios del distrito de Inclusa, sigs. 4-468-1 y 4-469-1.

El análisis del censo electoral de Inclusa en 1869 ejemplifica lo señalado. Más de tres cuartas partes del mismo eran trabajadores del sector de la producción. Sólo considerándose a los jornaleros dentro del anterior grupo puede observarse su protagonismo en esta zona. Alcanzaban casi una tercera parte del mercado laboral del distrito (31,11\%) y algo más de un $40 \%$ en su propio sector profesional. Unas proporciones que generaban bruscos contrastes con respecto a los niveles mostrados por profesionales liberales, oficinistas y funcionarios. La presencia comercial era igualmente reducida y se veía superada por la de trabajadores de servicios personales. Entre estos últimos, ya no sobresalían los integrantes masculinos del servicio doméstico interno, sino traperos, barrenderos, camareros, mozos de cuerda y aguadores.

Inclusa no era un distrito en el que no hubiera un tejido político establecido antes de 1868. Si bien en menor medida que en Centro, los progresistas también tenían articulada una organización relevante sobre la base del comité y de las subjuntas a nivel de barrio, que además había ejercido funciones decisivas en la lucha contra el cólera que asoló, con especial virulencia, a esta zona. La junta de socorros que se creó en el distrito ayudó a más de trescientas familias de este enclave en los momentos más complicados de la epidemia a mediados de octubre de 1865, distribuyendo 8.210 reales, 313 raciones de alimentos, mantas, sábanas

87 La Discusión, 16-1-1869 y 17-1-1869. 
y jergones en los domicilios y una gran cantidad de medicamentos ${ }^{88}$. Ahí participaron no sólo los presidentes de las mesas referenciados en el epígrafe anterior, sino también figuras que capitalizaron puestos de representación en la Junta Revolucionaria del distrito, como Juan y Joaquín Fernández Albert, Ildefonso Jacquet, Leandro Marichalar o Juan Chimaco, que ejercía la alcaldía del barrio de Huerta del Bayo movilizando el voto de sus vecinos.

Sin embargo, la progresiva inclinación de los habitantes del distrito hacia la opción republicana parecía evidente. En las elecciones municipales de diciembre de 1868, aquella únicamente obtuvo un $23,83 \%$ de los votos emitidos en las urnas. Apenas un mes después, ya había subido 18 puntos porcentuales y dos años más tarde, en las elecciones municipales de diciembre de 1871, conseguirian un triunfo íntegro, con seis concejalias de las siete que el partido obtuvo en toda la ciudad89. En el caso de los comicios de 1869, la movilización republicana llegó de diversos frentes. Al margen de los comités que crearon en los meses previos, cabría destacar las acciones realizadas por los jóvenes de entre veinte y veinticinco años del distrito, no sólo para reivindicar el derecho de elegir $\mathrm{y}$ ser elegidos en futuros comicios, sino también para realizar campañas de propaganda electoral ${ }^{90}$.

Tabla 8. Movilización del voto por categoria profesional en los barrios del distrito de Inclusa

\begin{tabular}{|c|c|c|c|c|c|c|}
\hline Barrio & $\begin{array}{c}\text { HISCO } \\
\mathbf{0 / 1}\end{array}$ & $\begin{array}{c}\text { HISCO } \\
\mathbf{3}\end{array}$ & $\begin{array}{c}\text { HISCO } \\
\mathbf{4}\end{array}$ & $\begin{array}{c}\text { HISCO } \\
\mathbf{5}\end{array}$ & $\begin{array}{c}\text { HISCO } \\
\mathbf{7 / 8 / 9}\end{array}$ & Jornaleros \\
\hline Cabestreros & $59,46 \%$ & $72,22 \%$ & $66,67 \%$ & $60 \%$ & $61,04 \%$ & $54,54 \%$ \\
\hline Caravaca ${ }^{91}$ & - & - & - & - & - & - \\
\hline Comadre & $56,25 \%$ & $61,43 \%$ & $54,93 \%$ & $51,14 \%$ & $53,20 \%$ & $41,62 \%$ \\
\hline Embajadores & $50 \%$ & $64,71 \%$ & $75,00 \%$ & $80 \%$ & $59,24 \%$ & $52,81 \%$ \\
\hline Encomienda & $65,91 \%$ & $72,73 \%$ & $72 \%$ & $52,31 \%$ & $66,75 \%$ & $59,84 \%$ \\
\hline $\begin{array}{c}\text { Huerta del } \\
\text { Bayo }\end{array}$ & $62,50 \%$ & $52,94 \%$ & $57,63 \%$ & $52,94 \%$ & $55,75 \%$ & $46,09 \%$ \\
\hline Peñón & $58,33 \%$ & $73,33 \%$ & $69,33 \%$ & $61,21 \%$ & $61,96 \%$ & $58,75 \%$ \\
\hline Peñuelas & $68,75 \%$ & $60 \%$ & $60 \%$ & $54,93 \%$ & $46,77 \%$ & $41,04 \%$ \\
\hline Provisiones & $17,39 \%$ & $70 \%$ & $64,29 \%$ & $43,06 \%$ & $60,49 \%$ & $55,09 \%$ \\
\hline Rastro & $58,33 \%$ & $65,00 \%$ & $74,81 \%$ & $58,54 \%$ & $55,62 \%$ & $50,83 \%$ \\
\hline $\begin{array}{c}\text { Media } \\
\text { distrito }\end{array}$ & $\mathbf{5 5 , 7 9} \%$ & $\mathbf{6 6 , 5 8} \%$ & $\mathbf{6 7 , 1 8 \%}$ & $\mathbf{5 6 , 0 7 \%}$ & $\mathbf{5 6 , 6 1 \%}$ & $\mathbf{4 9 , 4 4 \%}$ \\
\hline
\end{tabular}

Fuente: AVM-S, actas, libros-registros de electores y listas de votantes de las elecciones generales de 1869, barrios del distrito de Inclusa, sigs. 4-468-1 y 4-469-1.

88 La Soberania Nacional, 13-10-1865.

89 AVM-S, actas de las elecciones municipales de 1871, distrito de Inclusa, sig. 4-499-1.

90 La Igualdad, 17-1-1869.

91 Aunque dispone de datos relativos a su censo electoral, el barrio de Caravaca carece de listas de votantes en las actas tramitadas por el Ayuntamiento de Madrid. 


\section{Tabla 9. Movilización del voto por especialización profesional en los barrios del distrito de Inclusa}

\begin{tabular}{|c|c|c|c|c|}
\hline Especialización profesional & Votan & $\begin{array}{c}\text { No votan } \\
\text { o } \\
\text { carecen } \\
\text { de } \\
\text { cédulas } \\
\end{array}$ & Total & $\begin{array}{l}\text { Votan } \\
(\%)\end{array}$ \\
\hline Jornaleros & 1.159 & 1.185 & 2.344 & $49,45 \%$ \\
\hline $\begin{array}{c}\text { Zapateros y trabajadores de la confección } \\
\text { de cueros }\end{array}$ & 330 & 180 & 510 & $64,71 \%$ \\
\hline Ebanistas, carpinteros y similares & 320 & 148 & 468 & $68,38 \%$ \\
\hline Propietarios y dependientes de comercio & 301 & 141 & 442 & $68,10 \%$ \\
\hline Albañiles y trabajadores de la construcción & 222 & 162 & 384 & $57,81 \%$ \\
\hline $\begin{array}{c}\text { Trabajadores en procesado de comidas y } \\
\text { bebidas }\end{array}$ & 143 & 172 & 315 & $45,40 \%$ \\
\hline Empleados de la administración pública & 196 & 96 & 292 & $67,12 \%$ \\
\hline Herreros y artesanos del metal & 147 & 98 & 245 & $60 \%$ \\
\hline Sastres, modistos y similares & 144 & 61 & 205 & $70,24 \%$ \\
\hline Impresores y similares & 138 & 57 & 195 & $70,77 \%$ \\
\hline $\begin{array}{c}\text { Conductores de vehículos de tracción } \\
\text { animal }\end{array}$ & 55 & 67 & 122 & $45,08 \%$ \\
\hline Pintores de edificios y obras & 72 & 44 & 116 & $62,07 \%$ \\
\hline Tabernero & 66 & 22 & 88 & $75,00 \%$ \\
\hline Trabajadores del servicio doméstico & 40 & 42 & 82 & $48,78 \%$ \\
\hline Aguadores & 24 & 57 & 81 & $29,63 \%$ \\
\hline Canteros y mineros & 57 & 24 & 81 & $70,73 \%$ \\
\hline Mozos de cuerda & 41 & 32 & 73 & $56,16 \%$ \\
\hline
\end{tabular}

Fuente: AVM-S, actas, libros-registros de electores y listas de votantes de las elecciones generales de 1869, barrios del distrito de Inclusa, sigs. 4-468-1 y 4-469-1.

En líneas generales, el voto republicano en el distrito de Inclusa se intensificó en aquellos barrios que contaban con una proporción de trabajadores del sector de la producción superior a la media del distrito. Así ocurrió en Peñuelas, Caravaca y Huerta del Bayo, donde conformaban el 84,18\%, el 84,91\% y el 83,58\% de los vecinos que declaraban ocupación profesional respectivamente. Huerta del Bayo fue la única sección del distrito en la que vencieron los republicanos en estas elecciones. En términos proporcionales, la movilización no llegó proveniente tanto de los jornaleros, sino de un variopinto conjunto de artesanos cualificados entre los que se encontraban dueños de pequeños talleres de carpintería y ebanistería, cerrajeros, canteros, curtidores, impresores, encuadernadores, tipógrafos, pintores de obras y edificios, sastres y, sobre todo, zapateros y trabajadores de la industria del cuero y del calzado. La disyuntiva entre trabajadores cualificados $y$ no cualificados resultaba extrapolable a las otras nueve secciones electorales del distrito, si se observa cómo algo menos de la mitad de los segundos registrados en el censo acudieron a las urnas.

Los barrios de los distritos de Centro e Inclusa podian ser divergentes en estructura social y tendencia de voto, pero mostraban prácticas electorales similares. Así se demuestra en el análisis de sus listas de votantes, que ofrecen la posibilidad de determinar el orden en el que se producía la llegada de los electores a los colegios de cada barrio. En no pocas ocasiones, ese orden evidencia una participación en el proceso político más cercana a una experiencia colectiva que a una individualizada. Dicha experiencia afectaba a grupos muy 
diversos. A los que coincidian en el interior de un mismo bloque residencial, cuyos vínculos se tejían a través de las relaciones sociales desarrolladas en el vecindario; a quienes compartían una misma especialización profesional en el entorno socio-comunitario de una zona o a aquellos que habían construido lazos de solidaridad a través del paisanaje. Marc Brodie ha puesto énfasis en estas cuestiones, remarcando dos advertencias. La primera tiene que ver con la importancia de no tratar a los individuos del pasado de manera aislada, presentando sus actitudes políticas como el resultado de decisiones tomadas desde una base estrictamente personal. Y la segunda entronca con la conveniencia de pensar que las relaciones sociales podian resultar decisivas a la hora de determinar la forma en la que la gente actuaba en términos políticos ${ }^{92}$.

La interpretación del acto del voto como una experiencia social compartida o deudora de vínculos interpersonales es algo que podría sugerirse observando el marco de un mismo bloque residencial. Así ocurría en las fincas 6 y 8 del callejón de Tudescos, situada a espaldas de la actual Gran Vía; en el número 4 de la calle del Espejo, a mitad de camino entre las calles del Arenal y Mayor; o en el número 11 de la calle de Rodas, en los espacios intersticiales entre la calle de Embajadores y la Ribera de Curtidores. Sus inquilinos presentaban grandes similitudes en lo que respecta a la forma en que se desenvolvía su vida. La mayoria eran empleados de servicios personales, modestos artesanos o trabajadores no cualificados que ocupaban alguna de las numerosas y económicas viviendas interiores que copaban aquellas humildes estructuras arquitectónicas. Resulta plausible la idea de que era el estrecho contacto que mantenían de manera cotidiana el factor que les llevaba a acudir conjuntamente a los colegios electorales. A buen seguro lo hacían aquellos que convivian en una habitación, no sólo unidos por lazos familiares, sino también por estrategias de compartimentación del alquiler que abonaban por la misma con sus frágiles o intermitentes ganancias salariales. Era el caso de los jornaleros Miguel García Ríos y Andrés Vietes, de los molenderos Antonio Hernández, José Freire, Francisco Suárez y José Rodríguez y de los barrenderos Manuel Lendón, Alonso Silva y Gabriel Galdeque. Pero también lo hacian quienes quedaban unidos por el ejercicio de una misma profesión sin compartir estancia residencial, como los carpinteros Antonio Charlán, Baltasar Sancho y Pedro Diaz, los estuquistas Manuel Enríquez y José María Ripoll o los albañiles Ángel Martínez y Manuel Meginos.

En términos profesionales, la práctica conjunta del voto era un patrón denominador común para los integrantes de ciertos oficios que con el transcurso de los años y la modernización de los servicios urbanos fueron perdiendo representatividad en Madrid. Ocurría con los aguadores, los verduleros y los mozos de cuerda. En lineas generales, eran figuras laborales que en el espacio urbano desarrollaban unas estrategias de corresidencia en las que jugaban un papel relevante las penurias económicas que podian atravesar. Sin embargo, dicha convivencia también respondía al establecimiento de sólidas redes de solidaridad basadas en el paisanaje. Entre aquellos trabajadores existian unos vínculos de amistad y hermandad ya señalados en diversos estudios y explicados

\footnotetext{
${ }^{92}$ Marc Brodie, "Friendship, trust and political influence in poor working-class Britain", History of Australia, vol. 3, $\mathrm{n}^{\circ}$ 2, 2006, pp. 41.1-41.11.
} 
en función de una procedencia geográfica unívoca o, al menos, muy próxima93. Todos ellos eran vínculos que podian trasvasar el plano residencial y laboral para extrapolarse a la participación electoral. El fenómeno del paisanaje podría explicar por qué los mozos de cuerda afincados en las señaladas fincas de los números 6 y 8 del callejón de Tudescos acudieron juntos a votar al colegio electoral del barrio de Silva en el distrito de Centro, de la misma forma que lo hicieron los verduleros que residian en la casa número 14 de la calle de Santa Ana en el barrio de Peñón o los aguadores empadronados en el número 13 de la calle de Comadre en el barrio del mismo nombre, los dos últimos en el distrito de Inclusa. No obstante, y sin ánimo de ser deterministas, cabría valorar otras posibilidades a la hora de comprender ese comportamiento. Y una de las más significativas tendría que ver con el influjo moral que sobre el ejercicio de su sufragio podrian haber jugado autoridades municipales como los alcaldes de barrio. No en vano, la expedición de las licencias de aguadores y mozos de cuerda dependía del Ayuntamiento de Madrid.

El posible influjo moral sobre los anteriores gremios llevaría a considerar otros escenarios en los que el voto podia quedar condicionado por redes sociales de dependencia ${ }^{94}$. Tanto en el momento de su inauguración como en la Restauración, el ejercicio del sufragio universal podia venir determinado por el paternalismo que definía a los vínculos establecidos en un oficio. Casos evidentes podian encontrarse en el comercio, donde las relaciones entre propietarios y dependientes se regían por la lógica que imponía el sistema del internado ${ }^{95}$, o en ciertos establecimientos industriales. Parecía esclarecedor en la confitería que regentaba Carlos Prast en la calle del Arenal, teniendo en cuenta que sus dos dependientes internos participaron en el proceso electoral del mismo modo que su patrón, acudiendo juntos a votar tanto la mesa electoral del barrio como las candidaturas los dias 15 y 16 de enero. También en el negocio que tenía José María López en el número 13 de la cuesta de Santo Domingo, dedicado a la venta de pollos, valorando la forma en la que concurrió al colegio electoral del barrio de Prim junto a sus cuatro dependientes: Ramón Villa, Francisco Mayo, Domingo Veloso y Benito Díaz. E idéntico escenario se contemplaria en la fábrica de pastas que Luis López regentaba en el número 5 de la Costanilla de Santiago (barrio de Prim), si se analiza la correspondencia entre su comportamiento electoral y el de sus cuatro empleados, esto es, Juan Cazón (expendedor del establecimiento); Domingo López (repartidor); José López (oficial); y José Quiroga (aprendiz) ${ }^{96}$.

El análisis del voto a nivel de barrio permite advertir fenómenos reseñables como los anteriores, pero también otros que generalmente pasan desapercibidos. Uno de ellos tiene que ver con la espontaneidad que en cierto modo caracterizó a

93 Juan Jiménez Mancha, Asturianos en Madrid. Los oficios de las clases populares (siglos XVIXX), FMCE-Muséu del Pueblu d'Asturies, Gijón, 2007.

94 Frank O'Gorman, Voters, patrons and parties: the unreformed electoral system of Hanoverial England, 1734-1832, Clarendon Press, Oxford, 1989 y Michel Offerlé, Le vote et la vertu, op. cit., pp. 55-95.

95 Autor, 2017.

96 Todos los datos relacionados con el acto del voto asociado a relaciones interpersonales y relaciones sociales de deferencia y dependencia proceden del análisis cruzado de la siguiente documentación: AVM-S, listas de votantes de las elecciones generales de 1869, distritos de Centro y de Inclusa, sigs. 4-460-1, 4-499-3, 4-468-1 y 4-469-1 y AVM-E, Rectificación del Padrón de Habitantes de Madrid de 1868. 
los primeros procesos electorales del Sexenio. No cabe olvidar que los comicios de 1869 se celebraron al amparo del sistema de las listas abiertas. Si bien se repartían papeletas impresas con las candidaturas elegidas por los comités de los partidos a nivel de distrito, los electores tenían la oportunidad de modificarlas, tachando los nombres oficiales o sustituyéndolos por otros. Asimismo, los votantes tenían la posibilidad de utilizar papeletas manuscritas, rellenadas en sus domicilios o en los locales de votación, de acuerdo con lo consignado por el artículo 34 de la normativa electoral.

El sistema de listas abiertas permitiria entender por qué algunos barrios reflejaron escrutinios muy alejados de la tónica general de las jornadas de votación. El más sorprendente se corresponde con el barrio de Puente de Toledo, en el distrito de Latina, situado en una zona que abarcaba las viviendas comprendidas al sur de la urbe desde la Puerta de Segovia hasta los pontones de San Isidro, dirigiéndose después hacia las carreteras de Carabanchel y Andalucía. Lo más destacado de esa sección fue que el triunfo correspondió a una personalidad desligada de las candidaturas oficiales: Pedro Martínez Luna.

Pedro Martínez Luna no era una figura cualquiera en el Madrid isabelino. Avalado por su condición de gran propietario, habia participado de manera intensa en los procesos electorales desde los años cuarenta, primero como responsable de la organización técnica de los comicios legislativos desde las mesas electorales y posteriormente como candidato a las concejalias, siempre en el Partido Progresista. Las primeras elecciones municipales en las que intervino fueron las de 1845, compitiendo precisamente por el distrito de Latina ${ }^{97}$. Sin embargo, su significación politica a nivel municipal no llegaría hasta las jornadas revolucionarias de 1854 y el Bienio Progresista. Tras las luchas en las barricadas tomó partido en las juntas auxiliares de salvación y defensa ${ }^{98}$, desempeñando, a continuación, la tenencia de alcaldía del distrito de Latina desde el Ayuntamiento de Madrid.

Durante la década siguiente, Martínez Luna encabezó la junta directiva del Partido Progresista del distrito de Latina en cuestiones electorales y ejerció de nuevo el cargo de concejal. Con el nuevo episodio revolucionario de 1868, su nombre volvió a salir a la palestra en esa zona, siendo elegido diputado propietario de la Junta Superior Revolucionaria de Madrid y quedando designado como concejal del Ayuntamiento ${ }^{99}$. Sin duda alguna, estos precedentes eran más que suficientes para entender por qué en algunos colegios del distrito se votó de manera significativa a esta figura. Sin embargo, lo que llama la atención del barrio de Puente de Toledo radica en el hecho de que casi dos terceras partes de los votantes escribieron su nombre en las papeletas depositadas en las urnas ${ }^{100}$. El vecindario de este enclave no tuvo tanto en cuenta el protagonismo que aquel adquirió en la dimensión política de las revoluciones de 1854 y 1868. Por el

97 El Clamor Público, 10-12-1845.

98 La Nación, 3-8-1854 y 30-8-1854.

99 AVM-S, LAAM, sesión inaugural del 13 de octubre de 1868.

100 Martínez Luna obtuvo 415 votos de los 616 depositados en las urnas, superando con claridad a Juan Prim (365 votos). En: AVM-S, actas de las elecciones generales de 1869, distrito de Latina, barrio de Puente de Toledo, sig. 4-470-1. 
contrario, su comportamiento electoral resultó más bien deudor del capital social que el candidato extraoficial había atesorado en esa zona.

Martínez Luna luchó con tesón para mejorar las condiciones de habitabilidad de los vecinos de una zona periférica y olvidada por las autoridades municipales y trató de compensar las desgracias personales que algunos de ellos vivieron antes de 1868. Mención especial merecen en este apartado los trabajos desarrollados para sofocar un incendio ocurrido en las eras del camino de Carabanchel, a raíz del cual se determinó la instalación de bocas de riego en la barriada $^{101}$, y las propuestas para el establecimiento de nuevos servicios que presentó desde su cargo de concejal, entre los que destacaban la creación de escuelas y la colocación de faroles para mejorar la iluminación. Estas medidas entraban de lleno en la vía de los progresos que reclamaban los vecinos de los barrios del sur y sus afueras, crecientes en población y en necesidades:

\begin{abstract}
"Alli faltan fuentes de vecindad y las clases trabajadoras hay ocasiones en que no tienen agua para apagar su sed, en tanto que no se aprovecha la que por lujo se vierte y corre en la Puerta del Sol; alli todo escasea - alumbrado, empedrado, apertura de nuevas vías, acordadas hace años - y a pesar de esto y estar su utilidad reconocida, nunca principiadas a realizarse en grande o pequeña escala; alli parece que pesa la fatalidad; allí no se introducen mejoras, y si hay quien las pida (que si hay en el municipio y en la prensa), o se hace oídos de mercader con sus peticiones o si éstas se aceptan al fin, pasan días y meses y años como si tal cosa"102.
\end{abstract}

Pero, ante todo, Martínez Luna se ganó el reconocimiento de sus vecinos con los trabajos que desarrolló para corregir la situación higiénico-sanitaria de aquel espacio urbano. La epidemia de cólera de 1865 y la alarma social a raíz de los casos presentados en las casas inmediatas al río Manzanares hizo comprender el absoluto desamparo en el que se presentaban los habitantes del barrio. El concejal progresista ya había concebido anteriormente la necesidad de establecer una Casa de Socorro en la zona para hacer frente a este tipo de situaciones, pero no fue hasta ese momento cuando consiguió su objetivo. Durante la epidemia, Martínez Luna prestó toda clase de auxilios a los invadidos y a sus familias, poniendo a su disposición las habitaciones de su vivienda y cediendo carruajes a los médicos facultativos para agilizar los servicios de la asistencia domiciliaria ${ }^{103}$. Cuando se extinguió la enfermedad y cesaron las tareas de la Casa de Socorro provisional establecida en el barrio, fue el primero en plantear la creación de un servicio de asistencia médica permanente, tal y como expuso en una nota dirigida a Sagasta, entonces director de La Iberia ${ }^{104}$.

Las actuaciones de Martinez Luna se vieron recompensadas en las primeras elecciones en las que los vecinos del barrio de Puente de Toledo pudieron participar, a pesar de que no figurara en ninguna de las candidaturas oficiales. Quienes le apoyaron decidieron tachar el nombre de Sagasta en la lista oficial monárquico-democrática para incluir el suyo. Sus votantes, ya fueran jornaleros,

101 La Iberia, 16-9-1865.

102 La cita, de Pedro Martínez Luna, en: La Iberia, 15-7-1863.

103 AVM-S, Circulares del Ayuntamiento de Madrid. Sobre servicios prestados por Pedro Martinez Luna durante la epidemia colérica en el distrito de Latina, sig. 14-23-3.

104 La Iberia, 26-11-1865. 
canteros, carpinteros, zapateros, arrieros u hortelanos, carecían de derechos políticos antes de las jornadas revolucionarias, con lo que su triunfo resulta una demostración evidente de cómo unos comicios, organizados sobre la base de unas listas abiertas, podian dar lugar resultados excepcionales en zonas carentes de cualquier actividad política en los tiempos en que el sufragio se entendia en términos de capacidad económica y profesional y no como un derecho de la ciudadanía.

Tabla 10. Movilización del voto por categoria profesional en el barrio de

Puente de Toledo

\begin{tabular}{|c|c|c|c|c|c|}
\hline $\begin{array}{c}\text { Categoria } \\
\text { profesional }\end{array}$ & Votan & $\begin{array}{c}\text { No votan o } \\
\text { carecen de } \\
\text { cédulas }\end{array}$ & Total & $\begin{array}{c}\text { \% sobre } \\
\text { total } \\
\text { trabajadores }\end{array}$ & Participación \\
\hline $\begin{array}{c}\text { Profesionales } \\
\text { liberales y técnicos }\end{array}$ & 5 & 6 & 11 & $1,16 \%$ & $45,45 \%$ \\
\hline $\begin{array}{c}\text { Trabajadores } \\
\text { administrativos y } \\
\text { de gestión }\end{array}$ & 1 & - & 1 & $0,11 \%$ & $100 \%$ \\
\hline $\begin{array}{c}\text { Oficinistas y } \\
\text { funcionarios }\end{array}$ & 3 & 2 & 5 & $0,53 \%$ & $60 \%$ \\
\hline $\begin{array}{c}\text { Trabajadores de } \\
\text { ventas }\end{array}$ & 43 & 16 & 59 & $6,24 \%$ & $72,88 \%$ \\
\hline $\begin{array}{c}\text { Trabajadores de } \\
\text { servicios } \\
\text { personales }\end{array}$ & 21 & 13 & 34 & $3,59 \%$ & $61,76 \%$ \\
\hline $\begin{array}{c}\text { Agropecuarios y } \\
\text { forestales }\end{array}$ & 25 & 15 & 40 & $4,23 \%$ & $62,50 \%$ \\
\hline $\begin{array}{c}\text { Trabajadores del } \\
\text { sector de la } \\
\text { producción }\end{array}$ & 502 & 294 & 796 & $84,14 \%$ & $63,07 \%$ \\
\hline Total & $\mathbf{6 0 0}$ & $\mathbf{3 4 6}$ & $\mathbf{9 4 6}$ & $\mathbf{1 0 0 \%}$ & $\mathbf{6 3 , 4 2 \%}$ \\
\hline $\begin{array}{c}\text { Jornaleros sobre } \\
\text { total de } \\
\text { trabajadores }\end{array}$ & 313 & 224 & 537 & $56,76 \%$ & $58,29 \%$ \\
\hline
\end{tabular}

Fuente: AVM-S, actas de las elecciones generales de 1869, distrito de Latina, barrio de Puente de Toledo, sig. 4-470-1.

Puente de Toledo era un barrio virginal en términos electorales como también lo eran algunos de los que acababan de incorporarse a Madrid tras la materialización del Ensanche. Uno de ellos era el de Delicias, principal motor demográfico del Ensanche Sur junto al barrio de Peñuelas ${ }^{105}$. Delicias constituía uno de los espacios sobre los que se había gestado el derribo de la cerca fiscal de Felipe IV y la ampliación de los límites de la ciudad en su parte meridional, a

105 De acuerdo con las listas de electores que se aplicaron en los comicios generales de marzo de 1867, el barrio de Delicias únicamente registraba diez habitantes con derecho al voto. Sus nombres y las condiciones que garantizaban tal derecho eran las siguientes: A. Alotán (contribuyente, 34 escudos anuales), Antonio Carrasco (contribuyente, 24 escudos anuales), Juan Clote (contribuyente, 136 escudos anuales); Pedro Danguerretegui (contribuyente, 89 escudos anuales); Mateo Espallardo (contribuyente, 20 escudos anuales); Cipriano Pinilla (contribuyente, 22 escudos anuales); Jorge Monforte (contribuyente, 24 escudos anuales); Miguel Ortiz (contribuyente, 307 escudos anuales); Juan Pendaries (capacidad) y Antonio Varela (contribuyente, 21 escudos anuales). En: AVM-S, listas rectificadas de los electores para diputados a Cortes pertenecientes a Madrid en 1867, sig. 4-302-2. 
medida que aquella se fue poblando y especialmente a renglón seguido de la apertura de la Estación del Mediodía. A la altura de 1869, aquel enclave servía como un espacio residencial apto para los inmigrantes que llegaban a Madrid huyendo de las penurias económicas del medio rural. Sus principales vías de desarrollo urbanístico, si bien todavía carente de los más básicos servicios e infraestructuras, eran la calle del Sur (actual Méndez Álvaro) y el Paseo de las Delicias. Al margen de por su impronta popular y por la presencia de trabajadores ferroviarios, Delicias constituía un barrio en el que todavía se respiraban aires característicos de una identidad rural. Junto a los citados docks y los talleres de construcción ferroviaria, concentraba tejares, huertas y casas de matanza ${ }^{106}$.

A buen seguro que, para los vecinos y propietarios del barrio de las Delicias, las elecciones municipales y generales celebradas en el transcurso de un mes resultaron una oportunidad de primera magnitud para tener la visibilidad que hasta entonces obviaron las autoridades. Como señalaron algunos de ellos en un escrito dirigido al Ayuntamiento en 1870, sus peticiones pidiendo la regularización del barrio habían sido sistemáticamente desatendidas por todas las anteriores administraciones, principalmente en lo que se refería al estado del alcantarillado, de ciertas casas ruinosas y de los cerros de la zona, cubiertos de inmundicias ${ }^{107}$. En aquel espacio tampoco habia una articulación social y política previa y esta circunstancia se demostró en las urnas. En los comicios locales se abrazaron con firmeza los principios del republicanismo. Algo más de un 60\% de quienes votaron lo hicieron en favor de la candidatura formada por Pedro Pallarés, Estanislao Figueras, Diego López Santiso y José Guisasola108. Un porcentaje de apoyo social que fue similar al contemplado un mes después, si bien en unas condiciones de movilización muy distintas.

Teniendo en cuenta la distribución de las cédulas de vecindad a la hora de medir la abstención en las elecciones generales de 1869, es significativo que en el barrio de Delicias se pasara de una afluencia en las urnas de apenas un $25 \%$ en los comicios municipales de diciembre de 1868 a otra que alcanzaba el 61,60\% en enero del año siguiente. También creció la participación en la elección de la mesa electoral, insignificante en la primera de esas fechas y caracterizada por una enconada lucha en la segunda, que finalmente tuvo como vencedores a habitantes que se acababan de iniciar en la actividad politica y en la militancia republicana. El más relevante era Pedro Iza, un ebanista que habitaba en la calle del Sur, que consiguió hacerse con la presidencia. Con la representación de este cargo inició su carrera política al lado de los federales durante el Sexenio. Un año después, en la elección parcial de un diputado a Cortes, comenzó a encargarse de las tareas de supervisión relativas al reparto de las cédulas, formando parte de las comisiones de vigilancia que se crearon para reclamar las que no eran recibidas por electores republicanos ${ }^{109}$. A mediados de 1870 , ya trasladado al

106 Fernando Vicente, El Ensanche Sur. Arganzuela, 1860-1931. Los barrios negros, Catarata, Madrid, 2016.

107 AVM-S, Expediente promovido por varios propietarios y vecinos de la calle del Sur, pidiendo la regularización del barrio de Delicias, 1870, sig. 5-68-46.

108 AVM-S, actas de las elecciones municipales de 1868, distrito del Hospital, barrio de Delicias, sig. 4-450-1.

109 La Igualdad, 8-1-1870. 
barrio de Santa Bárbara en el distrito de Hospicio, se encargó de dirigir los trabajos de aquella zona relativos a la elección de la Junta Municipal del Partido Republicano Federal ${ }^{110}$. Y finalmente, en diciembre de 1871 , presentó su candidatura para optar a la concejalía de la anterior demarcación por el Ayuntamiento de Madrid ${ }^{111}$.

Al igual que en otros barrios populares del sur, la primera jornada de votación en Delicias fue poco alentadora para los republicanos. En la mesa electoral sólo se dieron cita 94 electores. Rivero dobló en votos al republicano más apoyado, José María Orense. Un primer balance poco prometedor que se borró de un plumazo un día después. La presencia de electores en el local fue masiva. Las dos terceras partes de los 253 alli congregados depositaron 167 papeletas con la candidatura oficial republicana. El escrutinio final de la sección, completado con otra jornada de enorme tranquilidad el lunes 18 , dejó un resultado contundente e insólito en el resto de la ciudad: el republicanismo doblaba en votos a la candidatura monárquico-democrática ${ }^{112}$.

\section{Tabla 11. Movilización del voto por categoria profesional en el barrio de Delicias}

\begin{tabular}{|c|c|c|c|c|c|}
\hline Categoria profesional & Votan & $\begin{array}{c}\text { No votan o } \\
\text { carecen de } \\
\text { cédulas }\end{array}$ & Total & $\begin{array}{c}\text { \% total } \\
\text { trabajadores }\end{array}$ & Participación \\
\hline $\begin{array}{c}\text { Profesionales liberales } \\
\text { y técnicos }\end{array}$ & 4 & 9 & 13 & $2,21 \%$ & $30,77 \%$ \\
\hline $\begin{array}{c}\text { Trabajadores } \\
\text { administrativos y de } \\
\text { gestión }\end{array}$ & 2 & 6 & 8 & $1,36 \%$ & $25,00 \%$ \\
\hline $\begin{array}{c}\text { Oficinistas y } \\
\text { funcionarios }\end{array}$ & 52 & 30 & 82 & $13,92 \%$ & $63,41 \%$ \\
\hline $\begin{array}{c}\text { Trabajadores de ventas } \\
\text { servicios personales }\end{array}$ & 13 & 7 & 20 & $3,39 \%$ & $65,00 \%$ \\
\hline $\begin{array}{c}\text { Agropecuarios y } \\
\text { forestales }\end{array}$ & 12 & 9 & 23 & $3,90 \%$ & $69,57 \%$ \\
\hline $\begin{array}{c}\text { Trabajadores del sector } \\
\text { de la producción }\end{array}$ & 254 & 168 & 422 & $71,64 \%$ & $67,14 \%$ \\
\hline Totales & $\mathbf{3 5 3}$ & $\mathbf{2 3 6}$ & $\mathbf{5 8 9}$ & $\mathbf{1 0 0 \%}$ & $\mathbf{5 9 , 9 3 \%}$ \\
\hline $\begin{array}{c}\text { Jornaleros sobre total } \\
\text { de trabajadores }\end{array}$ & 176 & 105 & 281 & $47,70 \%$ & $62,63 \%$ \\
\hline
\end{tabular}

Fuente: AVM-S, actas de las elecciones generales de 1869, distrito del Hospital, barrio de Delicias, sig. 4-462-1.

En Delicias, la práctica política concernió en casi dos terceras partes del electorado que votó a trabajadores del sector de la producción. Las representaciones de profesionales liberales, trabajadores de ventas y trabajadores de servicios personales eran mínimas, sintomáticas del perfil social de la zona. Únicamente se apartaban de esa lógica oficinistas y funcionarios, si bien caracterizados por salarios muy modestos. Dentro del sector mayoritario del

110 La Igualdad, 10-6-1870.

111 La Igualdad, 8-12-1871.

112 AVM-S, actas de las elecciones generales de 1869, distrito del Hospital, barrio de Delicias, sig. 4-462-1. 
trabajo manual se encontraban carpinteros, ebanistas, herreros, tejeros, yeseros, maquinistas y fogoneros de la Estación del Mediodía, aunque nuevamente sobresalian los jornaleros. Estos evidenciaron una presencia en las urnas más significativa que sus homólogos en Inclusa, lo que denota su mayor movilización en la cita electoral.

Tanto las características profesionales de Delicias como sus condiciones residenciales se asemejaban a las presentadas en el barrio de las Peñuelas, el otro gran germen de desarrollo poblacional del Ensanche Sur. También resultaba cierto que la práctica totalidad de los habitantes de aquel espacio recientemente anexionado a Madrid no tenian experiencia en citas electorales previas. Sin embargo, algunos de los propietarios y vecinos de mayor renombre allí empadronados ya se habían insertado en las filas progresistas del distrito de Inclusa antes de 1868 y habian realizado actividades politicas y asistenciales que pudieron influir en el escrutinio de las urnas del barrio en 1869. Camilo Laorga era el caso más destacado. Desde su condición de gran industrial, especializado en trabajos de ebanistería, había participado en el comité del Partido Progresista del citado distrito y en sus iniciativas electorales y asistenciales. Al igual que otros nombres apuntados en este artículo, tomó un papel activo en la lucha contra el cólera en 1865 y se adhirió con orgullo a los nuevos tiempos revolucionarios a finales de septiembre de 1868. Formó parte de la Junta Revolucionaria Interina creada en el distrito y de la Superior Revolucionaria de Madrid, jugando al mismo tiempo un rol fundamental en el sostenimiento del orden público y la seguridad de su barrio ${ }^{113}$.

Laorga ya se llevó el apoyo del vecindario del barrio de Peñuelas cuando este tuvo ocasión de votar en las elecciones municipales de diciembre de 1868. Sin embargo, también existian otras figuras que, en aquel espacio, mostraban sendas similares a la del industrial. Sintomático era el caso del aparejador Luis Pané, instalado en esa zona en 1857 y habitual interlocutor de las reclamaciones de los propietarios de la misma ante el Ayuntamiento, en la mayoría de los casos relativas a su abandono y a su falta de higiene y recursos. Pané coincidió con Laorga en la junta de socorros creada durante la epidemia de cólera ${ }^{114}$ e intervino de manera decidida en algunas de las primeras e importantes gestiones asumidas por el Ayuntamiento de Madrid tras la supresión de la Junta Superior Revolucionaria, como la preparación de la sustitución del impuesto de consumos por el de capitación ${ }^{115}$. En sus manos cayó la presidencia de la mesa elegida con ocasión de los comicios de 1869, tras ser abrumadoramente votado por los electores del barrio.

La nómina de vecinos de Peñuelas que ya habían evidenciado sus ambiciones políticas antes de 1868 se completaba con nombres como el del médico Silvestre Viñas, el del farmacéutico de la Beneficencia Rafael Carnicero, los de los propietarios Esteban Rosel y Francisco Gundián, el del fabricante de papel Juan Fernández Iglesias o el del almacenista de maderas Rafael Urosa ${ }^{116}$.

113 Un detallado recorrido biográfico por la trayectoria de Laorga en el barrio de Peñuelas en: Fernando Vicente, Los barrios negros: el Ensanche Sur en la formación del moderno Madrid (18601931), Tesis Doctoral, UCM, Madrid, 2011.

114 Fernando Vicente, Los barrios negros, op. cit., pp. 66-67; 84-85 y 351-353.

115 El Imparcial, 24-11-1868.

116 La Iberia, 1-11-1865. 
La mayoria había coincidido en diferentes ocasiones con Cayetano Palomares, un profesor de primera enseñanza afincado en la plaza de las Peñuelas que también había participado intensamente en el movimiento vecinal del barrio, formando parte de la comisión creada bajo el liderazgo de Laorga para presentar sus reivindicaciones a la corporación municipal en octubre de $1865^{117}$. Junto a Laorga, Palomares fue una de las figuras más activas del barrio en los meses que siguieron al triunfo revolucionario, presentándose como candidato a las elecciones de la Junta Revolucionaria del distrito a principios de octubre de 1868 y ejerciendo como secretario escrutador en las municipales de diciembre y en las generales de enero de 1869.

En definitiva, Peñuelas tenía un acervo progresista que salió a relucir en los comicios generales de 1869 y que frenó el predicamento que el republicanismo comenzaba a obtener en la zona, fruto de la propaganda desarrollada en el distrito. La diferencia que observó con respecto al barrio adyacente de Delicias en tendencia de voto podía responder precisamente a la existencia de las redes y los tejidos políticos articulados por figuras como Laorga y compañía antes de 1868, circunstancia que también es sugerida en los estudios que Rubén Pallol ha dedicado al desarrollo de estas elecciones en dos barrios también incorporados a Madrid con el plan de Ensanche, si bien en su parte norte (Chamberí y Campo de Guardias) ${ }^{118}$.

\section{CONCLUSIONES}

La aprobación del sufragio universal masculino tuvo unas implicaciones que, para el caso de Madrid, van más allá de las conclusiones que se puedan extraer de los esquemas analíticos arquetípicos de la sociología electoral clásica y de las interpretaciones que enfatizan los discursos y prácticas de la alta política e incluso los catecismos electorales para explicar la movilización del voto. La puesta en marcha de una inédita normativa electoral exige incidir en aspectos sobre los que, en lineas generales, no se ha problematizado lo suficiente. Para el caso de las primeras elecciones democráticas generales celebradas tras la Revolución de 1868, dichos aspectos se correlacionan con dos procesos fundamentales: votar y hacer votar en el marco de una vida politica amplificada.

Por una parte, el estudio de las elecciones de 1869 desde perspectivas asociadas a la materialidad del voto permite realizar interpretaciones que ya han tenido un notable calado en la historiografia europea. El objetivo de lograr una extensión social del sufragio conllevó el desarrollo de un proceso técnico complejo y sometido a dificultades que trataron de depurarse con el transcurso de los años, deudoras de problemas de improvisación organizativa, pero también de las propias características socio-económicas y residenciales de las áreas que conformaban la ciudad y del grado de habilitación real que su población tenía a la hora de ejercer el nuevo derecho político.

Por otro lado, la radiografía de la extensión social del sufragio en los primeros meses del Sexenio implica detenerse en los actores que guiaron la ejecución o aplicación práctica de la normativa electoral a nivel local, desde dos

117 Fernando Vicente, Los barrios negros, op. cit., pp. 283-284.

${ }^{118}$ Rubén Pallol, Una ciudad sin limites, op. cit. 
frentes entre los que se presentaron interconexiones. La exploración del proceso de configuración de las mesas electorales desde enfoques vinculados a la prosopografia y a la microhistoria permite vaticinar el liderazgo que asumían en sus barrios, clave para desempeñar un triple papel de arbitraje, mediación y movilización del voto. Precisamente el tercero de esos papeles, el de la movilización del voto, adquiere significación con interpretaciones realizadas sobre la base del barrio. La utilización de esa unidad analítica sugiere que tanto la participación popular en la cita electoral como la tendencia política del voto se rigieron por factores cambiantes, no sólo asociados a cuestiones materiales y de estructura social. En la participación electoral y el voto advertido en el Madrid de 1869 intervenían múltiples factores a tener en cuenta, como las relaciones interpersonales, los vínculos sociales trazados por el paisanaje, el oficio y el vecindario, los liderazgos comunitarios susceptibles de generar escrutinios apartados de la tónica oficial y la presencia/ausencia de tejidos asociativos articulados con anterioridad a la Revolución. Todo ello daba clara constancia de un panorama que revestía una notable complejidad en lo que respecto a los procesos de sociabilidad en el marco urbano y a los procesos de socialización en el escenario político.

Enviado el (Submission Date): 22/01/2020

Aceptado el (Acceptance Date): 14/03/2020 